\title{
地表面フラックス推定のための密度変動補正

\author{
小野圭介†
}

(独立行政法人農業環境技術研究所)

\section{Derivations and applications of the density correction for estimating surface flux}

Keisuke ONO $^{+}$

(National Institute for Agro-Environmental Sciences, Tsukuba, Ibaraki, 305-8604, Japan)

\begin{abstract}
The density correction, which is widely used in eddy covariance calculations to compensate for density fluctuations arising from heat and water vapor transfer in order to determine the surface (ecosystem) flux of a gaseous constituent such as $\mathrm{CO}_{2}$, was revisited based on its historical background and recent discussions. Firstly, the derivations previously published were categorized into three by their prerequisites: (1) mean vertical wind (the conventional Webb-Pearman-Leuning derivation), (2) expansion/compression of air parcel, and (3) the mass balance and continuity of both the target constituent and dry air. All the categories of derivation implicitly or explicitly assume no sink/source of dry air at the surface and arrive at the same equation for the correction, which relates an eddy covariance flux from mass or molar density measurements to the corresponding mixing ratio flux. Secondly, we examined the underlying assumptions or concepts used in those derivations, especially mean vertical wind to compensate for the turbulent flux of dry air. Thirdly, practical aspects of the density correction were considered for both open- and closed-path eddy covariance, and critical problems such as sensor heating of an open-path IRGA were also discussed. Our conclusions were that the density correction is theoretically sound as long as there is no sink/source of dry air at the surface but difficult to apply correctly because, in disagreement with its theory, different sensors with different time constants, which are usually positioned separately, are used in actual eddy covariance systems to calculate the correction terms. Closed-path systems are advantageous over open-path systems under such a condition that the surface flux is expected to be an order smaller in magnitude than the correction terms, due to their ability to point-by-point convert density measurements to the mixing ratios using the temperature, pressure and water vapor density that are simultaneously measured in the gas analyzer.
\end{abstract}

Key words: $\mathrm{CO}_{2}$ flux, Density correction, Eddy covariance, WPL correction.

キーワード : 渦相関法, $\mathrm{CO}_{2}$ フラックス, WPL 補正, 密度変動補正

\section{1. はじめに}

渦相関法に代表される微気象学的手法を用いた $\mathrm{CO}_{2}$ フラックスおよび蒸発散量の計測は, 今日の生 態系の炭素・水循環プロセスの実証研究で中心的な 役割を果たしている (e.g., Saigusa et al., 2008; Hirata et al., 2008; Ohta et al., 2008)。しかし, 微気象学的手法 は, 原理的には大気中の乱流フラックスを計測する 方法であり，それを地表面フラックス(生態学的フ ラックス)と見なすためには測定を追加したりデータ

2012 年 1 月 30 日 受付, 2012 月 3 月 30 日 受理

†Corresponding Author: onok@affrc.go.jp
処理を適切に行ったりする必要がある。例えば, 森 林サイトでは, 群落内の $\mathrm{CO}_{2}$ 濃度プロファイルから 推定した貯留変化量を乱流フラックスに加えること が一般に行われている (e.g., Ohkubo et al., 2007)。ま た, タワー周囲の植生がパッチ状に分布するサイト では, 乱流フラックスに寄与したエリアの分布と強 度を推定するためにフットプリント解析が必要とな る(e.g., Lloyd, 1995)。さらに, 顕熱・潜熱輸送が生 じているところでは，赤外線ガス分析計 (IRGA) で測 定した $\mathrm{CO}_{2}$ 密度に地表面フラックスに起因しない変 動が加わるため, 実測したフラックスに対して密度 変動補正が必要となる。

密度変動補正とは, 測定された $\mathrm{CO}_{2}$ 密度変動から 
熱や水蒸気による乾燥空気の密度変動を取り除く操 作である。一般には Webb et al. (1980)の Eqs. 24, 25 を指し，筆頭著者にちなんで Webb 補正，あるいは 共著者の姓の頭文字を取って WPL 補正と呼ばれる。 しかし，本稿では，Webb et al.（1980)の基礎となる 平均鉛直風速の概念を検証する目的もあり，その概 念から導かれた Webb et al. (1980)の Eqs. 24，25の みをWPL 補正とし, 同じ式が導かれたとしても前 提条件が異なる他の導出についてはより一般的な密 度変動補正という呼称を用いる。WPL 補正について は 1980 年前後にほぼ確立されており (Smith and Jones, 1979; Webb et al., 1980), 補正式自体に誤りは ないが, 解釈や適用条件ついては現在に至るまで議 論が続けられている (Leuning, 2004; Massman, 2004; Liu, 2005; Massman and Tuovinen, 2006; Kowalski and Serrano-Ortiz, 2007; Leuning, 2007; Kondo and Tsukamoto, 2008; Lee and Massman, 2010)。Webb et al. (1980) が発表されて 30 年となる 2010 年には，Webb et al. (1980)が公表される経緯にも言及した総説的な 論文 (Lee and Massman, 2010)が発表された。このよ うに注目を浴び続けている背景として, 1990 年中盤 以降, EUROFLUX, AmeriFlux, AsiaFlux 等の枠組 みの中で, 生態系炭素収支の長期変動の把握に渦相 関法で測定された $\mathrm{CO}_{2}$ フラックスが重用されたこと, それらのプロジェクトの成功によって渦相関法が本 来想定していない条件・サイトでフラックスモニタ リングが行われるようになったこと, さらに測器の 進歩により密度変動補正を必要とするオープンパス 型渦相関法が急速に普及したことが挙げられる。分 スケールの $\mathrm{CO}_{2}$ フラックスの積算值として年スケー ルの生態系炭素収支を算出するアプローチでは, $\mathrm{CO}_{2}$ フラックス測定值のわずかな誤差が様々に伝播 する可能性があるため, 補正まで含めた個々の測定 值の精度向上が求められた。また, Webb et al. (1980) は定常状態の 1 次元の流れを前提としている が，現実にそのような条件を満たすサイトは少なく， 3 次元, 非定常の流れについても適用可能なことを 厳密に検証する必要があった。水面でも熱や水蒸気 の交換が生じている限りは密度変動補正は必須であ る。1970 年代, 渦相関法によるフラックス計測の黎 明期には, 海洋を対象としている研究者が密度変動 補正の確立に大きく貢献した (e.g., Smith and Jones, 1979)。海面では $\mathrm{CO}_{2}$ フラックスが絶対的に小さい ため, 密度変動補正の精度に関連した議論は, 海洋 分野のコミュニティでも盛んに続けられている (e.g., Prytherch et al., 2010; Tsukamoto and Kondo, 2011)。

これまでの密度変動補正に関する議論は全体とし て収束される方向にあるが，未だ十分な合意が得ら
れていない部分もある。Webb et al. (1980)が補正式 を導出する際に用いた平均鉛直風速の概念，および クローズドパス型への適用方法である。さらに, 密 度変動補正が加減の演算で成り立っているという点 も, 密度変動補正の精度を議論する際に十分に考慮 されていない。そこで本稿では，これらに対して一 定の見解を示すこと，およびそれに基づいて密度変 動補正の本質についての理解を深めることを目的と して, 密度変動補正の論点を原理と適用方法に分け て整理し解説する。まず，第 2 節では，大気中の $\mathrm{CO}_{2}$ 密度変動の内訳を明らかにし, 微気象学的手法 で地表面フラックスを推定する際に $\mathrm{CO}_{2}$ 混合比が決 定的に重要であることを示す。次に, 第 3 節では, 複数ある密度変動補正の導出方法がいずれも最終的 には $\mathrm{CO}_{2}$ 密度変動から $\mathrm{CO}_{2}$ 混合比変動を求める作業 であることを示し，加えて，平均鉛直風速等の理解 が容易でない概念について詳説する。このような理 論的な背景に基づいて, 第 4 節では, 密度変動補正 を適用する際の留意点を, オープンパス型とクロー ズドパス型に分けて解説する。近年, 渦相関法への 適用を想定したオープンパス型の $\mathrm{CH}_{4}$ 分析計が市販 化され，より小さいフラックスを測定するために密 度変動補正の重要性はますます高まっている。本稿 は $\mathrm{CO}_{2}$ を対象とするが，水蒸気も含めて他の気体に ついても問題の本質は同一であり, $\mathrm{CO}_{2}$ を他の気体 に読み替えることで適用可能である。

\section{2. 密度変動補正の理論と導出}

密度変動補正は, 単位体積中の $\mathrm{CO}_{2}$ の分子数また は質量と鉛直風速 $w$ の共分散として算出した鉛直乱 流フラックスを地表面での $\mathrm{CO}_{2}$ 吸収・放出強度 (地 表面フラックス) に関係づけるための操作である。 $\mathrm{CO}_{2}$ に対してアクティブではない地表面上であって も，測定高度近傍の温度勾配（顕熱フラックス）に よって $\mathrm{CO}_{2}$ 密度が変動することから明らかなように, 大気中で測定した $\mathrm{CO}_{2}$ 密度の変動は, 地表面での $\mathrm{CO}_{2}$ の吸収・放出と必ずしも一致しない。本節では, まず，地表面でのプロセスと関連づけるために $\mathrm{CO}_{2}$ 混合比の変動を求める必要があることを示す。次に, $\mathrm{CO}_{2}$ の密度変動と混合比変動の関係式から, 大気中 の密度フラックスと地表面フラックスとを関連づけ る式を導出する。この導出は, これまで複数の研究 により試みられているが，ここでは 3 種類に類型化 し論点を整理する。このうちの一つが，いわゆる WPL 補正 (Webb et al., 1980) である。

\section{1 大気中の $\mathrm{CO}_{2}$ 密度変動の内訳}

微気象学的手法によるフラックス計測で用いられ る $\mathrm{CO}_{2} \cdot \mathrm{H}_{2} \mathrm{O}$ 分析計は, 赤外線の吸光度から $\mathrm{CO}_{2}$ 
(あるいは $\mathrm{H}_{2} \mathrm{O}$ ) の分子数密度を高速で計測する。 $\mathrm{CO}_{2}$ 分子数密度は, 混合比の定義より

$$
\rho_{\mathrm{c}}=\rho_{\mathrm{d}} \chi_{\mathrm{c}}
$$

と表せる。ここで， の体積混合比, 添え字 $\mathrm{d}$ と $\mathrm{c}$ は, 各々乾燥空気と $\mathrm{CO}_{2}$ を示す。式を簡略化するため, 本稿では Leuning （2004）あるいは Ibrom et al.（2007）に倣って気体密度 を質量ではなく分子数を用いて表す。また, Webb et al. (1980) と同様に, 乾燥空気には $\mathrm{CO}_{2}$ （あるいは対 象とする大気成分)を含まない。式(1)をレイノルズ 分解し, 変動成分を取り出すと

$$
\rho_{\mathrm{c}}^{\prime}=\bar{\rho}_{\mathrm{d}} \chi_{\mathrm{c}}^{\prime}+\bar{\chi}_{\mathrm{c}} \rho_{\mathrm{d}}^{\prime}
$$

を得る。式(2)は, $\mathrm{CO}_{2}$ 密度の変動が混合比のみなら ず乾燥空気密度の影響を受けることを意味する。混 合比はその定義より熱または水蒸気の出入りによら ず保存される量であり, $\mathrm{CO}_{2}$ 分子の実質的な増減に 対応する (Kowalski and Serrano-Ortiz, 2007; Lee and Massman, 2010)。したがって, IRGA で測定した $\rho_{\mathrm{c}}^{\prime}$ のうち, 地表面の $\mathrm{CO}_{2}$ 交換に対応するのは $\bar{\rho}_{\mathrm{d}} \chi_{\mathrm{c}}^{\prime}$ で あり, $\bar{\chi}_{\mathrm{c}} \rho_{\mathrm{d}}^{\prime}$ は熱または水蒸気の出入りにともなう 変動とみなすことができる。

さらに両辺に鉛直風速 $w$ の変動成分 $w^{\prime}$ を乗じて平 均操作を行うと,

$$
\overline{w^{\prime} \rho_{\mathrm{c}}^{\prime}}=\bar{\rho}_{\mathrm{d}} \overline{w^{\prime} \chi_{\mathrm{c}}^{\prime}}+\bar{\chi}_{\mathrm{c}} \overline{w^{\prime} \rho_{\mathrm{d}}^{\prime}}
$$

となり, 地表面で $\overline{w^{\prime} \rho_{\mathrm{d}}^{\prime}}=0$ と見なせる場合は, 地表 面の $\mathrm{CO}_{2}$ 交換に対応するのは $\bar{\rho}_{\mathrm{d}} \overline{w^{\prime} \chi_{\mathrm{c}}^{\prime}}$ となる。その ため, 大気中では, IRGA で測定した $\overline{w^{\prime} \rho_{\mathrm{c}}^{\prime}}$ から $\bar{\chi}_{\mathrm{c}}$ $\overline{w^{\prime} \rho_{\mathrm{d}}^{\prime}}$ を差し引いて $\bar{\rho}_{\mathrm{d}} \overline{w^{\prime} \chi_{\mathrm{c}}^{\prime}}$ を求める必要がある。

一般に， $\rho_{\mathrm{d}}^{\prime}$ を直接測定することは容易ではなく， 他の要素から算出寸る必要がある。湿潤空気を乾燥 空気， $\mathrm{H}_{2} \mathrm{O}, \mathrm{CO}_{2}$ の混合気体と見なせば,

$$
\begin{aligned}
& \bar{\rho}_{\mathrm{m}}=\bar{\rho}_{\mathrm{d}}+\bar{\rho}_{\mathrm{v}}+\bar{\rho}_{\mathrm{c}} \\
& \rho_{\mathrm{m}}^{\prime}=\rho_{\mathrm{d}}^{\prime}+\rho_{\mathrm{v}}^{\prime}+\rho_{\mathrm{c}}^{\prime}
\end{aligned}
$$

となる。ここで, 添え字の $\mathrm{v}$ と $\mathrm{m}$ はそれぞれ水蒸気 と湿潤空気を表す。通常 $\bar{\rho}_{\mathrm{c}}$ は $\bar{\rho}_{\mathrm{v}}$ より 1 桁以上小さ く， $\rho_{\mathrm{c}}^{\prime}$ は相対的にさらに影響が小さいため (Lee and Massman, 2010), 以後は省略する。 $\rho_{\mathrm{c}}$ 自身の効果を 加味した厳密な導出は Fuehrer and Friehe (2002)に示 されている。 $p$ を気圧, $T$ を気温, $R^{*}$ を普遍気体定 数とすると, 理想気体の状態方程式から

$$
\rho_{\mathrm{m}}=\frac{p}{R^{*} T}
$$

を得る。式(6)の変動成分は, $T / \bar{T} \ll 1, \bar{\chi}_{\mathrm{v}} \approx \bar{\rho}_{\mathrm{v}} / \bar{\rho}_{\mathrm{d}}$ を仮定し

$$
\rho_{\mathrm{m}}^{\prime}=\bar{\rho}_{\mathrm{d}}\left(1+\bar{\chi}_{\mathrm{v}}\right)\left(\frac{p^{\prime}}{\bar{p}}-\frac{T^{\prime}}{\bar{T}}\right)
$$

となり，式(7)を式(5)に代入することで， $\rho_{\mathrm{d}}^{\prime}$ を

$$
\rho_{\mathrm{d}}^{\prime}=-\rho_{\mathrm{v}}^{\prime}+\bar{\rho}_{\mathrm{d}}\left(1+\bar{\chi}_{\mathrm{v}}\right)\left(\frac{p^{\prime}}{\bar{p}}-\frac{T^{\prime}}{\bar{T}}\right)
$$

と表せる。省略した $T$ の高次の項については, 影響 が極めて限定的であることが実測データから確認さ れている(Lee and Massman, 2010)。式(8)および式 (2)より

$$
\bar{\rho}_{\mathrm{d}} \chi_{\mathrm{c}}^{\prime}=\rho_{\mathrm{c}}^{\prime}+\bar{\chi}_{\mathrm{c}} \rho_{\mathrm{v}}^{\prime}+\bar{\rho}_{\mathrm{c}}\left(1+\bar{\chi}_{\mathrm{v}}\right)\left(\frac{T^{\prime}}{\bar{T}}-\frac{p^{\prime}}{\bar{p}}\right)
$$

を得る。乱流フラックスについては，式(9)に $w^{\prime}$ を 乗じて平均操作を行うか, 式(3)に式(8) を代入して,

$$
\bar{\rho}_{\mathrm{d}} \overline{w^{\prime} \chi_{\mathrm{c}}^{\prime}}=\overline{w^{\prime} \rho_{\mathrm{c}}^{\prime}}+\bar{\chi}_{\mathrm{c}} \overline{w^{\prime} \rho_{\mathrm{v}}^{\prime}}+\bar{\rho}_{\mathrm{c}}\left(1+\bar{\chi}_{\mathrm{v}}\right)\left(\overline{\frac{w^{\prime} T^{\prime}}{\bar{T}}}-\frac{\overline{w^{\prime} p^{\prime}}}{\bar{p}}\right)
$$

の関係を導くことができる。共分散じうしの演算に よって密度フラックスから混合比フラックスを推定 するこの式を, 通常, フラックスの密度変動補正 (式)と呼ぶ。より高次のモーメントに対する密度変 動補正は，Detto and Katul (2007)の Eq. 9 等と同様に, 式(2)に基づいて導出できる。以上から明らかなよう に, 密度変動補正の実体は $\mathrm{CO}_{2}$ 密度変動と混合比変 動の関係式(式 2)であり，風速場やその定常性とは 直接関係しない。式(3), 式(10)では乱流フラックス ベクトルの鉛直成分のみを示したが，水平成分につ いても同様である。また，㛜密には，密度変動補正 は, 測器の不完全性あるいは誤差を修正するための 「補正」ではなく, 測定した密度フラックスと地表面 フラックスを関係づけるために必要な「adjustment」

(Suyker and Verma, 1993)である (Massman, 2004)。

なお，海洋を対象とした研究分野では，式(2) と式 （8）を用いて， $\mathrm{CO}_{2}$ 混合比の変動およびフラックスを それぞれ

$$
\begin{gathered}
\bar{\rho}_{\mathrm{d}} \chi_{\mathrm{c}}^{\prime}=\rho_{\mathrm{c}}^{\prime}+\left[\frac{\rho_{\mathrm{v}}^{\prime}}{\bar{\rho}_{\mathrm{d}}}+\left(1+\bar{\chi}_{\mathrm{v}}\right)\left(\frac{T^{\prime}}{\bar{T}}-\frac{p^{\prime}}{\bar{p}}\right)\right] \bar{\rho}_{\mathrm{c}} \\
\bar{\rho}_{\mathrm{d}} \overline{w^{\prime} \chi_{\mathrm{c}}^{\prime}}=\overline{w^{\prime} \rho_{\mathrm{c}}^{\prime}}+\left[\frac{\overline{w^{\prime} \rho_{\mathrm{v}}^{\prime}}}{\overline{\rho_{\mathrm{d}}}}+\left(1+\bar{\chi}_{\mathrm{v}}\right)\left(\overline{\frac{w^{\prime} T^{\prime}}{\bar{T}}}-\frac{\overline{w^{\prime} p^{\prime}}}{\bar{p}}\right)\right] \bar{\rho}_{\mathrm{c}}
\end{gathered}
$$

と表す場合もある。ここで，右辺第 2 項は希勫効果 
(dilution effect)に対する補正と位置づけられている (e.g., Fairall et al., 2000; McGillis et al., 2001)。一方, 陸域を対象としたフラックス計測分野では，希釈効 果は, クローズドパス型ガス分析計を用いた際の水 蒸気の増減の影響のみを指す場合が多い (e.g., Ibrom et al., 2007; Haslwanter et al., 2009)。

\section{2 密度変動補正の導出バリエーション}

前項では, $\mathrm{CO}_{2}$ 密度変動の内訳を明らかにするこ とで，地表面フラックスを推定するために混合比フ ラックスを求める必要があることを直感的に示した。 本項では, 地表面フラックスと混合比フラックスの 等価性をより理論的に導出する。この導出は, 1970 年代から最近に至るまで様々な方法により試みられ てきたが，一部を除いて最終的には同一の式(式 10) に到達している。これらは, 平均鈆直風速，気塊の 圧縮・膨張, 質量保存の式のいずれかを用いて式を 展開しており，この観点から類型化が可能である。 そこで，以下ではこの 3 類型について，各々の仮定， 展開，論点について詳述する。

\subsection{1平均鉛直風速を利用した導出}

最初は，乾燥空気分子の乱流フラックスを平均鉛 直風速に読み替えて

$$
\overline{w \rho_{\mathrm{c}}}=\overline{w^{\prime} \rho_{\mathrm{c}}^{\prime}}+\bar{w} \bar{\rho}_{\mathrm{c}}
$$

の $\bar{w}$ に代入する方法で, 密度変動補正が提案された 当時から導入されており，認知度は最も高い。これ を採用した Webb et al. (1980)の式(WPL 補正) は, 密 度変動補正の代名詞となっている。ただし, 後述 (3. 2)のように，ここで定義される平均鉛直風速 $\bar{w}$ は必 ずしも実体を伴わないものであり，解釈には注意を 要する。

渦相関法によるフラックス計測において，平均鈆 直風速の重要性を最初に指摘したのは Webb and Pearman (1977)であった。Webb and Pearman (1977) は，収束・発散が生じていない場所でも上向きの水 蒸気輸送を補償する平均鉛直風速 $\bar{w}$ が存在し得ると して，この流れによる $\mathrm{CO}_{2}$ 輸送を考慮する必要があ ることを強調した。Webb and Pearman（1977）は，乾 燥空気には正味の輸送が生じないこと $\left(\overline{w \rho_{\mathrm{d}}}=0\right)$ を明 示し, $\overline{w \rho_{\mathrm{m}}}-\overline{w \rho_{\mathrm{v}}}=\overline{w \rho_{\mathrm{d}}}=0$ から, $\bar{w}$ を

$$
\bar{w}=\frac{\overline{w \rho_{\mathrm{v}}}}{\bar{\rho}_{\mathrm{m}}}
$$

と表したが，ここで $\overline{w^{\prime} \rho_{\mathrm{m}}^{\prime}} / \bar{\rho}_{\mathrm{m}}=0$ とされ，暗に水蒸 気輸送がすべてが平均流によることが仮定されてい る。これに対して, Jones and Smith (1978)は, 水蒸

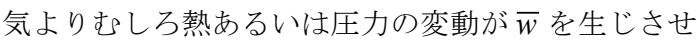
ると考えた。Jones and Smith (1978)は，海面あるい
は地表面での $\overline{w \rho_{\mathrm{m}}}=0$ を境界条件とし， $\bar{w}$

$$
\bar{w}=\frac{\overline{w^{\prime} \rho_{\mathrm{m}}^{\prime}}}{\bar{\rho}_{\mathrm{m}}}
$$

と表した。式(7)を用いると，式(15)は

$$
\bar{w}=\left(\overline{\frac{w^{\prime} T^{\prime}}{\bar{T}}}-\frac{\overline{w^{\prime} p^{\prime}}}{\bar{p}}\right)
$$

となり，温度と圧力のみの関数となる。ただし， Jones and Smith (1978)の原著では, $\rho_{\mathrm{m}}^{\prime}$ の導出におい て $\rho_{\mathrm{m}}^{\prime}$ を $\rho_{\mathrm{d}}^{\prime}$ と混同してしまったため, 式(16)の右辺 に $\overline{w^{\prime} \rho_{\mathrm{v}}^{\prime}}$ が含まれてしまっている。Jones and Smith （1978）と同年には，Bakan（1978）も式(16)を得てい る。Bakan (1978) は $\rho_{m}^{\prime}$ の展開において $\rho_{m}^{\prime}$ と $\rho_{d}^{\prime}$ の混 同はない。境界条件から明らかなように，式(14)は 地表面で顕熱フラックスが存在しない場合, 式 (15) は地表面で潜熱フラックスが存在しない場合を想定 しているが，実際の多くの地表面では顕熱フラック スと潜熱フラックスが同時に生じているため,これ らの補正式の実用性は低い。

地表面で顕熱フラックスと潜熱フラックスが同時 に生じている場合， $\overline{w \rho_{\mathrm{d}}}=0$ を境界条件として湿潤 空気と乾燥空気を厳密に区別した導出が必要である。 Smith and Jones (1979) は, $\overline{w \rho_{\mathrm{d}}}=0$ を境界条件とし, $\bar{w}$ を

$$
\bar{w}=\frac{\overline{w^{\prime} \rho_{\mathrm{d}}^{\prime}}}{\bar{\rho}_{\mathrm{d}}}
$$

と表した。 $\rho_{\mathrm{d}}^{\prime}$ については，湿潤空気を乾燥空気と水 蒸気の混合気体と仮定して式(8) を導き，最終的に式 （10）と同等の式に到達した。Webb et al. (1980)では 圧力相関項 $\overline{w^{\prime} p^{\prime}} / \bar{p}$ を省略しており，この点で Smith and Jones（1979）は Webb et al. (1980)より厳密に密度 変動補正を導出したと言える。ただし， Smith and Jones（1979）は，実測できる要素から各項を計算でき るように式中で湿潤空気の密度 (分子量)を用いてお り, Webb et al. (1980)に比べ一般化が十分ではない。

Webb et al. (1980) (WPL 補正) は密度変動補正の標 準的リファレンスとして確固たる地位を築いている が (Lee and Massman, 2010)，境界条件，導出された 式は Smith and Jones（1979）とほぼ同一であり，むし ろ最終的に $\overline{w^{\prime} p^{\prime}} / \bar{p}$ を含めたという点では Smith and Jones（1979）がより正確である。両者ともに，混合比 の計測により密度変動補正が不要になるという指摘 を行っており, 問題の核心についての理解は一致し ている。受理は, 厳密には Webb et al. (1980)が 1 日 早いが，相互に引用を行っていないことから， Smith and Jones（1979）とWebb et al. (1980)は本来独立して 
同等に評価されるべき研究である。

\subsection{2 気塊の圧縮・膨張の概念を利用した導出}

次は, 測定高度周りに存在する温度, 気圧, 水蒸 気の勾配の中を気塊が移動することで生じる圧縮・ 膨張の効果を $\rho_{\mathrm{c}}^{\prime}$ から差し引く方法で, 密度変動補正 の必要性が認識される契機 (Desjardins and Lemon, 1974; Jones and Smith, 1977) となった概念である。2. 1 で示した導出と同様に, WPL 理論が必要とした平 均鉛直風速の概念を用いない点に最大の特徵がある。 ただし， $\rho_{\mathrm{c}}^{\prime}$ から差し引くべき体積変動の効果を乾燥 空気のそれと同一とみなしている点で地表面で乾燥 空気の交換がないことを暗に前提としている。

この概念では, 大気中の $\mathrm{CO}_{2}$ 密度変動 $\rho_{\mathrm{c}}^{\prime}$ を

$$
\rho_{\mathrm{c}}^{\prime}=\rho_{\mathrm{c}, \mathrm{sur}}^{\prime}+\rho_{\mathrm{c}, \mathrm{ext}}^{\prime}
$$

と表す (Massman and Tuovinen, 2006; Detto and Katul, 2007）。ここで， $\rho_{\mathrm{c} \text {,sur }}^{\prime}$ は地表面フラックスに起因し た変動, $\rho_{\mathrm{c}, \mathrm{ext}}^{\prime}$ は気塊の圧縮・膨張にともなう変動で ある。 $\rho_{\mathrm{c}, \mathrm{ext}}^{\prime}$ を

$$
\frac{\rho_{\mathrm{c}, \mathrm{ext}}^{\prime}}{\bar{\rho}_{\mathrm{c}}}=\frac{\rho_{\mathrm{d}}^{\prime}}{\bar{\rho}_{\mathrm{d}}}
$$

と表せば， $\bar{\chi}_{\mathrm{c}} \approx \bar{\rho}_{\mathrm{c}} / \bar{\rho}_{\mathrm{d}}$ より, 式(18)は式(2)と同等と 見なせる。すなわち， $\rho_{\mathrm{c} \text {, sur }}^{\prime}=\bar{\rho}_{\mathrm{d}} \chi_{\mathrm{c}}^{\prime}$ である。さらに， 式(18)および式(19)に式(8) を代入し $w^{\prime}$ を乗じると, 式(10)を得る。

近年，この概念に基づいた新たな補正方法が提案 された(Liu, 2005)。Liu（2005)は， $\rho_{c \text {,ext }}^{\prime}$ が体積 $V$ の 変化 $V^{\prime}$ にると仮定し，それを

$$
\frac{V^{\prime}}{\bar{V}}=\frac{\rho_{\mathrm{m}}^{\prime}}{\bar{\rho}_{\mathrm{m}}}
$$

で表した。しかし, 式(19) と比較しても明らかなよ うに, 式(20)には $\mathrm{H}_{2} \mathrm{O}$ の増減の効果が含まれておら ず，暗に地表面での $\overline{w \rho_{\mathrm{m}}}=0$ を前提としてしまって いる。さらに, 体積変化と密度変化の式を混用して しまったため，最終的に誤った補正式(Liu, 2005, Eq. 17) を導いている。前者の過誤については紙上討論と なり (Kowalski, 2006a, b; Liu, 2006)，後者については Massman and Tuovinen (2006)により問題のポイント が示されている。

\subsection{3 質量保存の式を利用した導出}

上記の 2 つの導出方法は, 地表面で $w \rho_{\mathrm{d}}=0$ とす る境界条件を巧みに利用し, 混合比フラックスが地 表面フラックスと等価であることを示した。これら は，いずれも密度変動補正の式として正しく，実用 上は問題ない(Kowalski and Serrano-Ortiz, 2007)。し かし，仮想的な平均鈆直風速を移流項に組み入れる
こと，あるいは乾燥空気の変動をすべて圧縮・膨張 に起因するものとして乾燥空気フラックスに関する 境界条件の明記を避けることは，いずれも導出方法 としてやや奇抜である。より整合性のある展開を行 うためには, 質量保存の式に立ち返り, 乾燥空気の ソース・シンクが存在しないこと

$$
\frac{\partial \rho_{\mathrm{d}}}{\partial t}+\nabla \cdot\left(\mathbf{u} \rho_{\mathrm{d}}\right)=0
$$

を明示的に用いる必要がある。ここで，u は風速べ クトルである。厳密には, 植物の光合成あるいは土 壌中の脱窒により $\mathrm{O}_{2}, \mathrm{~N}_{2}$ が生成されるため地表面で は式(21)の右辺は 0 ではないが，下のように $\mathrm{CO}_{2}$ の 質量保存を考える上では $\bar{\chi}_{\mathrm{c}}$ 倍となるため実用上は問 題ない (Leuning, 2004; Lee and Massman, 2010)

Paw U et al. (2000), Massman and Lee (2002), Leuning (2004)は, $\mathrm{CO}_{2}$ に関する質量保存の式

$$
\frac{\partial \rho_{\mathrm{c}}}{\partial t}+\nabla \cdot\left(\mathbf{u} \rho_{\mathrm{c}}\right)=S_{\mathrm{c}}
$$

に式(21)を組み込み, その結果として密度変動補正 項が現れること示した。ここで， $S_{\mathrm{c}}$ は $\mathrm{CO}_{2}$ のソー ス・シンク項を表す。これらの研究では，近似方法 等が各々で異なるため, 最終的に得られる式の形態 にも若干の相違がある。本稿では，仮定がより少な いMassman and Lee (2002)の導出について簡潔に説 明する。

まず，式(21)および式(22) を各々レイノルズ分 解・平均し,

$$
\begin{aligned}
& \frac{\overline{\partial \rho_{\mathrm{d}}}}{\partial t}+\nabla \cdot\left(\overline{\mathbf{u}^{\prime} \rho_{\mathrm{d}}^{\prime}}+\overline{\mathbf{u}} \bar{\rho}_{\mathrm{d}}\right)=0 \\
& \overline{\frac{\partial \rho_{\mathrm{c}}}{\partial t}}+\nabla \cdot\left(\overline{\mathbf{u}^{\prime} \rho_{\mathrm{c}}^{\prime}}+\overline{\mathbf{u}} \bar{\rho}_{\mathrm{c}}\right)=\bar{S}_{\mathrm{c}}
\end{aligned}
$$

を得る。続いて, 式(23)に $\bar{\chi}_{\mathrm{c}}$ を乗じ, 式(24)から差 し引き整理すると，

$$
\bar{\rho}_{\mathrm{d}} \frac{\overline{\partial \chi_{\mathrm{c}}}}{\partial t}+\nabla \cdot\left(\overline{\mathbf{u}^{\prime} \rho_{\mathrm{c}}^{\prime}}-\bar{\chi}_{\mathrm{c}} \overline{\mathbf{u}^{\prime} \rho_{\mathrm{d}}^{\prime}}\right)+\overline{\mathbf{u} \rho_{\mathrm{d}}} \cdot \nabla \bar{\chi}_{\mathrm{c}}=\bar{S}_{\mathrm{c}}
$$

となる。ただし，式(25)は Massman and Lee (2002) と異なり，空気の非圧縮性 $(\nabla \cdot \overline{\mathbf{u}}=0)$ を仮定していな い(Massman and Tuovinen, 2006)。地表面での $\mathrm{CO}_{2}$ の 交換が乱流輸送によらない $\left(\left(\overline{w^{\prime} \rho_{\mathrm{c}}^{\prime}}-\bar{\chi}_{\mathrm{c}} \overline{w^{\prime} \rho_{\mathrm{d}}^{\prime}}\right)_{0}=0\right)$ と 仮定し, 式(25) を地表面から測定高度 $z_{\mathrm{m}}$ まで積分す ると, 


$$
\begin{aligned}
& \int_{0}^{z_{\mathrm{m}}}\left(\bar{\rho}_{\mathrm{d}} \frac{\overline{\partial \chi_{\mathrm{c}}}}{\partial t}\right) \mathrm{d} z+\left(\overline{w^{\prime} \rho_{\mathrm{c}}^{\prime}}-\bar{\chi}_{\mathrm{c}} \overline{w^{\prime} \rho_{\mathrm{d}}^{\prime}}\right)_{z_{\mathrm{m}}} \\
& \quad+\int_{0}^{z_{\mathrm{m}}} \nabla_{\mathrm{H}} \cdot\left(\overline{\mathbf{u}^{\prime} \rho_{\mathrm{c}}^{\prime}}-\bar{\chi}_{\mathrm{c}} \overline{\mathbf{u}^{\prime} \rho_{\mathrm{d}}^{\prime}}\right) \mathrm{d} z \approx \int_{0}^{z_{\mathrm{m}}} \overline{S_{\mathrm{c}}} \mathrm{d} z
\end{aligned}
$$

となる。ここで， $\nabla_{\mathrm{H}}$ は水平方向のナブラ演算子であ る。式(26)の左辺第 1 項は貯留項, 左辺第 2 項は $z_{\mathrm{m}}$ での鉛直乱流フラックス, 左辺第 3 項は水平方向の フラックス発散項を地表面から $z_{\mathrm{m}}$ まで積分したもの で，右辺は地表面フラックス(生態系フラックス)に 相当する。式(3) と比べて明らかなように, 左辺第 2 項, 第 3 項は, 3 次元の流れであっても生態系フ ラックスと関係する乱流輸送として $\mathrm{CO}_{2}$ の混合比フ ラックスが適当であることを示している。また，平 均鉛直風速を用いた導出では $\overline{w \rho_{\mathrm{d}}}=0$ が用いられた が，ここでは乾燥空気に関して用いられたのは式 (21)のみである。なお, $\overline{\mathbf{u} \rho_{\mathrm{d}}} \cdot \nabla \bar{\chi}_{\mathrm{c}}$ は quasi advection と呼ばれる項を含む移流項で, 実測は困難であるが 質量保存の式を完全に閉じさせる場合には何らかの 方法で評価する必要がある (Massman and Lee, 2002; Lee and Massman, 2010)。様々な条件における式(25) の空間積分については Leuning（2004）または Lee and Massman (2010) に詳しく記されている。

\section{3. 密度変動補正の理論に関する論点}

以上のように，いずれの方法においても最終的に 導かれる補正式は式(10)であり, 地表面で乾燥空気 フラックスが存在しない限りはこの理論に誤りはな い。しかしながら, 導出方法によっては解釈が容易 でない概念を用いており，相互関係も理解しづらい。 ここでは, 誤解が生じやすい概念について, 上記の 導出方法に照らし合わせて検討する。

\section{1 乾燥空気ゼロフラックスの制約}

乾燥空気ゼロフラックス $\left(\overline{w \rho_{\mathrm{d}}}=0\right)$ の制約を課す位 置(地表面あるいは測定高度)によらず補正式として は式(10)が導出される。しかし, 適用条件を決定す る上でこの区別は重要である。平均鉛直風速を用い る導出では, 基本的に地表面での $\overline{w \rho_{\mathrm{d}}}=0$ を境界条 件としており，大気中(例えば測定高度)において $\overline{w \rho_{\mathrm{d}}}=0$ が満たされる必要はない。これに対し, Kowalski and Serrano-Ortiz (2007)は, Webb et al. $(1980)$ が大気中での $\overline{w \rho_{\mathrm{d}}}=0$ を用いたと指摘してい る。確かに, Webb et al. (1980)のこの点に関する記 述は明快ではないが, “there is no source or sink of air at the ground”とも記されており, 少なくとも地表面 では $\overline{w \rho_{\mathrm{d}}}=0$ であることを前提としていることから， Kowalski and Serrano-Ortiz (2007)の指摘は正確ではな い。通常の地表面では $\overline{w \rho_{\mathrm{d}}}=0$ であり, WPL 理論は
有効である。

\section{2 平均鉛直風速の解䣋}

一方, 平均鉛直風速 $\bar{w}$ の解釈については若干の注 意を要する。平均鉛直風速 $\bar{w}$ の導入は WPL 補正の 最大の特徵であるが, Webb et al. (1980)を始めとし て, $\bar{w}$ の概念を用いる研究のほとんどは $\bar{w} か ゙$ 補償 流として同じ平均化時間内に実在することを前提と している (e.g., Webb and Pearman, 1977; Jones and Smith, 1978; Smith and Jones, 1979; Paw U et al., 2000; Kowalski and Serrano-Ortiz, 2007)。Kowalski and Ser-

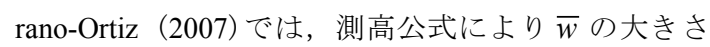
が詳細に見積もられている。しかし，WPL 補正が必 要と寸る $\bar{w}$ は, 式(17)から明らかなように, 乾燥空 気分子の乱流フラックスの影響を打ち消寸ために必 要な仮想的な流れであり, $\overline{w \rho_{\mathrm{c}}}$ のレイノルズ分解・ 平均に現れる $\bar{w}$ とは本質的に異なる。温度あるいは 水蒸気 (厳密には乾燥空気以外の寸べての大気成分) の鉛直分布に勾配が生じている条件下では，乾燥空 気に密度勾配が生じ，乱渦により乾燥空気分子が鉛 直方向に輸送される。この $\overline{w^{\prime} \rho_{\mathrm{d}}^{\prime}} \neq 0$ となる状況に対 して $\overline{w \rho_{\mathrm{d}}}=0$ たる境界条件を満たすため, $\bar{w} \neq 0$ を認 める必要があった。WPL 理論での $\bar{w} は$ は, あくまで $\overline{w^{\prime} \rho_{\mathrm{d}}^{\prime}}$ に対して定義されるものであり, 時間あるいは

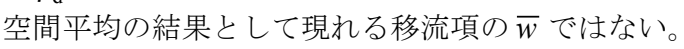
$-\overline{w^{\prime} \rho_{\mathrm{d}}^{\prime}} / \bar{\rho}_{\mathrm{d}}$ としての $\bar{w}$ は, 現実の非定常条件下にお いて, 超音波風速計によって測定される必要はない。 測定高度において $\overline{w \rho_{\mathrm{d}}}=0$ が成立する場合には WPL 理論における $\bar{w} は$ 移流項の $\bar{w}$ と一致するが，地表 面フラックスを推定する上での境界条件はあくまで 地表面における $\overline{w \rho_{\mathrm{d}}}=0$ である。

\section{3 非定常条件での適用}

日射あるいは放射冷却等により接地気層の密度が 時間とともに変化する非定常な状態であっても, そ の影響は乾燥空気と $\mathrm{CO}_{2}$ の両方に現れるため, 式 (10) はやはり有効である。平均鉛直風速を用いた導 出でも同様のことが言える。Leuning (2007) は, 地 表面から測定高度までの密度変化の効果を平均鉛直 風速に組み込み, それが地表面 $\mathrm{CO}_{2}$ フラックスの推 定には影響しないことを明らかにした。ただし，い ずれの場合も, 平均化の操作は式(10)に関わるず゙ ての項に対して同一の方法で行われなければならな い。ある変数 (例えば $T$ )に対してのみトレンド除去 等の異なる平均化操作を行うことは, 式(2)が閉じな い原因となる。

\section{4 熱収支インバランスの影響}

渦相関法で測定した顕熱フラックス $H$ と潜熱つ ラックス $\lambda E$ の和が有効エネルギー(正味放射量と地 中熱流量の和) と一致しない熱収支インバランスは世 
界の多くのタワー観測サイトで報告されており，現 在に至るまで根本的な解決に至っていない (Foken et al., 2011)。とくにオープンパス型では, 密度変動補 正に用いる $\overline{w^{\prime} \rho_{\mathrm{v}}^{\prime}}, \overline{w^{\prime} T^{\prime}}$ が熱収支観測と共用される 場合がほとんどであるため, 熱収支インバランスが 密度変動補正に及ぼす影響については関心が高い (Twine et al., 2000; Liu et al., 2006)。しかし，熱収支 インバランスがすべて密度変動補正に影響を及ぼす わけではない。

熱収支インバランスが密度変動補正に及ぼす影響 を考えるには，やはり式(10)に立ち返る必要がある。 熱収支インバランスの原因が風速との相関を含む 個々の測器の問題に起因する場合, 式(10)を通じて 密度変動補正に影響を及ぼす。例えば, 何らかの問 題で超音波風速計による $T^{\prime}$ が過小評価された場合， $\overline{w^{\prime} T^{\prime}}$ の過小評価を通じて $\bar{\rho}_{\mathrm{d}} \overline{w^{\prime} \chi_{\mathrm{c}}^{\prime}}$ が過小に算出され, 密度変動補正に負のバイアスが生じる。このときの 誤差の伝播は Liu et al. (2006)に詳しく記されている。 一方, 熱収支インバランスの原因が平均化操作で失 われた低周波領域の過小評価にある場合, 同じ平均 化操作を行う限り対象となる周波数帯が一致するた め, $\overline{w^{\prime} \rho_{\mathrm{v}}^{\prime}}, \overline{w^{\prime} T^{\prime}}$ と同様に $\overline{w^{\prime} \rho_{\mathrm{c}}^{\prime}}$ も過小評価となり, 密度変動補正には影響しない。むしろ, Twine et al. (2000)のように, $\overline{w^{\prime} \rho_{\mathrm{v}}^{\prime}}, \overline{w^{\prime} T^{\prime}}$ に対しての夕補正を 行うことは, 密度変動補正を過大評価寸ることにな る。近年, 熱収支インバランスの原因は主に平均化 時間より長周期の輸送の過小評価にあると考えられ ており (Foken, 2008)，その限りでは，地表面熱収支 インバランスの密度変動補正への直接の影響は限定 的と見なせる。

\section{4. 密度変動補正の適用に関する論点}

\section{1 密度変動補正の適用原則}

地表面で乾燥空気が交換されていないと見なせる 限り, 密度変動補正の式自体は, 導出方法によらず 理論的に誤りが無いことはこれまでに述べた通りで ある。したがって, 密度変動補正に関する過誤は, ほぼすべて適用時に生じる。

上記の導出から明らかなように, 密度変動補正は, 大気境界層内のある点における $\mathrm{CO}_{2}$ 密度変動と混合 比変動の関係式(式 2)に基づいており, 原理的には 式(10)右辺の各変数が, 同一点で同時に同一の周波 数応答特性を持った測器で計測され, 同一の平均化 操作を受けなければならない。しかしながら，実際 は, $\rho_{\mathrm{c}}$ と $\rho_{\mathrm{v}}$ を測定するオープンパス型 $\mathrm{CO}_{2} ・ \mathrm{H}_{2} \mathrm{O}$ 分 析計と $w$ を測定する超音波風速計との間には距離が ある上, 各々の測器で測定パスの長さやノイズ処理 方法も一様ではない。これらはコスペクトルの高周
波側の減衰に相違を生じさせる。通常，鉛直風速 $w$ と温度 $T$ (厳密には音仮温度 $T_{\mathrm{s}}$ ) は同じ超音波風速計 で測定されるため, $\overline{w^{\prime} T^{\prime}}$ の高周波減衰は最も小さい。 したがって，いずれの共分散にも周波数応答補正が 行われない場合， $\overline{w^{\prime} \rho_{\mathrm{c}}^{\prime}}$ あるいは $\overline{w^{\prime} \rho_{\mathrm{v}}^{\prime}}$ を含む項に対 して, $\overline{w^{\prime} T^{\prime}}$ を含む項が過大評価となる (e.g., Kondo and Tsukamoto, 2008)。同様に, いずれかの共分散の み周波数応答補正が行われたり, 誤った方法で周波 数応答補正が行われたりした場合にも, 各々の項が 整合しなくなる。一方, 測器のドリフトによらない 時系列のトレンドを何らかの方法で除去することは 低周波減衰を生じさせる(Moncrieff et al., 2004)。例 えば温度信号 $T$ についてのみトレンドを除去した場 合, $\overline{w^{\prime} T^{\prime}}$ が他の項に比べて過小評価となる。また, 超音波風速計とオープンパス型 $\mathrm{CO}_{2} \cdot \mathrm{H}_{2} \mathrm{O}$ 分析計の ように，厳密に同一の空気を測定していない場合に は, 各々が異なる変動を捉えている可能性もある。 後述するオープンパス型 $\mathrm{CO}_{2} \cdot \mathrm{H}_{2} \mathrm{O}$ 分析計の熱源問 題がこれに相当する。平均值の項についても同様に, 精度と測定位置が重要となる。オープンパス型 $\mathrm{CO}_{2} \cdot \mathrm{H}_{2} \mathrm{O}$ 分析計の光学窓の污れは平均值を変化さ せるため, 程度によっては致命的となる。複数の測 器を用いて密度変動補正を行う場合には, 各々の精 度を十分に保ち, 各信号に適切な処理 (主に周波数応 答補正)を行い, 1 つの測器で $\bar{\rho}_{\mathrm{d}} \overline{w^{\prime} \chi_{\mathrm{c}}^{\prime}}$ が測定された と見なせるようにすることが適用上の原則である。 これは, 次に述べるように, $\mathrm{CO}_{2}$ フラックスが小さ い場所ではとくに重要となる。

密度変動補正の最大の特徴は, 共分散どうしの演 算により混合比フラックスが求まる点であるが, 補 正式が共分散の和の形で表されるため, 支配項の誤 差の大きさが補正後も保たれるという側面も持つ。 例えば, 日中の裸地土壤面で, $\overline{w^{\prime} \rho_{\mathrm{c}}^{\prime}}$ が-10.0 $\mu \mathrm{mol} \mathrm{m}{ }^{-2}$

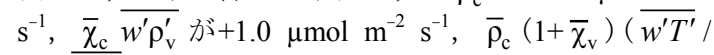
$\left.\bar{T}-\overline{w^{\prime} p^{\prime}} / \bar{p}\right)$ が+10 $\mu \mathrm{mol} \mathrm{m} \mathrm{m}^{-2} \mathrm{~s}^{-1}$ のとき, すべての項 が正しく測定されていれば補正後の $\mathrm{CO}_{2}$ フラックス $\bar{\rho}_{\mathrm{d}} \overline{w^{\prime} \chi_{\mathrm{c}}^{\prime}}$ は+1.0 $\mu \mathrm{mol} \mathrm{m} \mathrm{s}^{-2} \mathrm{~s}^{-1}$ である。しかし, 何らか の原因で $\overline{w^{\prime} \rho_{\mathrm{c}}^{\prime}}$ が-10.5 $\mu \mathrm{mol} \mathrm{m} \mathrm{m}^{-2} \mathrm{~s}^{-1}$ と見積もられた場 合, $\bar{\rho}_{\mathrm{d}} \overline{w^{\prime} \chi_{\mathrm{c}}^{\prime}}$ は+0.5 $\mu \mathrm{mol} \mathrm{m} \mathrm{m}^{-2} \mathrm{~s}^{-1}$ となり, 密度変動補

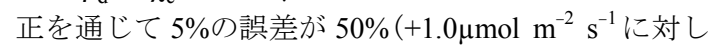
て $\left.-0.5 \mu \mathrm{mol} \mathrm{m} \mathrm{m}^{-2} \mathrm{~s}^{-1}\right)$ に増幅されたことになる。 $\bar{\rho}_{\mathrm{c}}$ が $5 \%$ 過小評価された場合も同様の誤差割合の増幅が生 じる。また, オープンパス型 $\mathrm{CO}_{2} \cdot \mathrm{H}_{2} \mathrm{O}$ 分析計につ いて, 超音波風速計とのセンサー間の距離に起因し て生じた 5\%の高周波減衰が補正されなかった場合 は, $\bar{\rho}_{\mathrm{d}} \overline{w^{\prime} \chi_{\mathrm{c}}^{\prime}}$ が+1.45 $\mu \mathrm{mol} \mathrm{m}{ }^{-2} \mathrm{~s}^{-1}$ となり，45\%の誤差 $\left(+1.0 \mu \mathrm{mol} \mathrm{m} \mathrm{s}^{-2}\right.$ に対して $\left.+0.45 \mu \mathrm{mol} \mathrm{m} \mathrm{s}^{-2}\right)$ となる。 したがって, 各測器が入念に校正されていることは 
もちろんであるが，各種補正を含めた支配項の䛊差 にはとくに注意を払う必要がある。密度変動補正適 用後のフラックスに対するサンプリング誤差 (e.g., Finkelstein and Sims, 2001) を評価する場合は, 各項の サンプリング誤差が平方和で加算されるため, 支配 項の影響がさらに強まる。

上述の思考実験から明らかなように, 地表面フ ラックスに対して補正項が桁違いに大きい場合, 密 度変動補正を通じて補正後のフラックスの精度が桁 落ちの状態となる。このような状態になりやすい冬 季の裸地, 雪面, あるいは絶対的に $\mathrm{CO}_{2}$ フラックス が小さい海面では, 密度変動補正の精度が著しく低 下寸る。また, 補正項の係数を考慮すると, $\lambda E$ と $H$ が同じ大きさであれば, $\overline{w^{\prime} T^{\prime}}$ を含む項が約 4〜 倍 寄与が大きいため, ボーエン比 $(H / \lambda E)$ が大きいサイ 卜も注意が必要である。今後, $\mathrm{CO}_{2}$ 濃度の高まりと ともに $\overline{w^{\prime} T^{\prime}}$ を含む項の影響はさらに増大する。

\section{2 圧力相関項の影響}

気体の状態方程式が示すように, 密度は温度のみ ならず圧力によっても変化するため, 厳密には式 (10)の気圧変動の項 $\overline{w^{\prime} p^{\prime}}$ を評価する必要がある。し かし, 一般的な気象条件では $\left|\overline{w^{\prime} p^{\prime}}\right||p \ll| \overline{w^{\prime} T^{\prime}} \mid / T$ であ ること (Webb et al., 1980), $\overline{w^{\prime} p^{\prime}}$ の計測自体が困難あ ることから, 通常の密度変動補正では評価の対象と されない場合がほとんどであった。これに対し，

Massman and Lee (2002), Zhang et al. (2010)は, p'の 測定を試み, その結果から, とくに長期連続測定に おける $\overline{w^{\prime} p^{\prime}}$ の重要性を主張している。 $\overline{w^{\prime} p^{\prime}}$ の評価は 今後も検討を継続しなければならないが，現段階で 大気中の $p^{\prime}$ を精度良く測定するのは容易ではないた め, $\overline{w^{\prime} p^{\prime}}$ が大きくなると思われる高風速, あるいは 粗度の大きい場所での長期連続測定では, クローズ ドパス型渦相関法の利用も考慮されるべきである。

Massman (2004) はクローズドパス型 $\mathrm{CO}_{2} \cdot \mathrm{H}_{2} \mathrm{O}$ 分析 計の測定セル内において $w$ と相関を持つ圧力変動が 増幅される可能性を指摘しているが, 現在広く使わ れているクローズドパス型 $\mathrm{CO}_{2} \cdot \mathrm{H}_{2} \mathrm{O}$ 分析計 (LI6262, LI-7000, LI-7200; LI-COR) はセル内の気圧変 動を測定するためのセンサーを備えており（LI-6262 の場合はオプション), それが適切に動作している限 りは問題にはならない。

\section{3 実際の適用方法}

渦相関法はオープンパス型とクローズドパス型に 大別できる。これらはいずれも赤外線吸光度により $\mathrm{CO}_{2}$ 密度を計測する IRGA を用いるため, 地表面フ ラックスを推定する際は密度変動補正が必須である。 ただし, フラックス計測に常用されているクローズ ドパス型 $\mathrm{CO}_{2} ・ \mathrm{H}_{2} \mathrm{O}$ 分析計 (LI-6262, LI-7000; LI-
COR）は, 測定セル内の温度, 気圧変動（に近いも の)の測定值を用いた内部演算によって混合比あるい はモル分率を出力するモードを備えており, その モードを適用した場合には, 出力值を混合比に変換 した上で $\bar{\rho}_{\mathrm{d}} \overline{w^{\prime} \chi_{\mathrm{c}}^{\prime}}$ に代入することで密度変動補正を 介さずに地表面フラックスを直接推定することがで きる (Leuning, 2004; Ibrom et al., 2007; Ono et al., 2007)。近年, 後述するセンサーの污れや熱源問題の 対策としてオープンパス型 $\mathrm{CO}_{2} \cdot \mathrm{H}_{2} \mathrm{O}$ 分析計の測定 パスをチャンバーで閉鎖して使用するタイプの分析 計（LI-7200；LI-COR)が市販されたが，本質的には クローズドパス型であり, 適切な演算によって混合 比 $\chi_{\mathrm{c}} お よ ひ ゙ \chi_{\mathrm{v}}$ を得ることができる (Nakai et al., 2011; Burba et al., 2012)。なお，オープンパス型渦相関法 においても超音波風速計の $T_{\mathrm{s}}$ を用いて生データの段 階で混合比への換算を試みることは可能である。し かし, 風向, 風速による超音波風速計とオープンパ 不型 $\mathrm{CO}_{2} \cdot \mathrm{H}_{2} \mathrm{O}$ 分析計の信号のずれを同期させにく く, また測器の応答特性を考慮しづらいため, 短時 間の実験的な解析 (e.g., Ono et al., 2008) を除いて, 絶 対值の精度が求められる長期連続測定には適してい ない。

オープンパス型とクローズドパス型のいずれも適 用時には個々のシステムの特性に応じて考慮すべき 点が多くあり，これらを統一的に理解することは容 易ではない。そこで，これまで提案されてきた適用 方法を整理しつつ, 現時点で最も適切と思われる手 順と留意点を以下に示す。さらに，発売から間もな い分析計，および今後利用が増えると思われる $\mathrm{CO}_{2}$, $\mathrm{H}_{2} \mathrm{O}$ 以外の分析計への適用についても言及する。

\subsection{1 オープンパス型渦相関法への適用}

オープンパス型渦相関法は, 超音波風速計に併置 したオープンパス型のガス分析計を用いて $\mathrm{CO}_{2}$ 等の 大気成分の密度変動をその場で測定する方法で, 現 時点では $\mathrm{H}_{2} \mathrm{O}, \mathrm{CO}_{2}, \mathrm{CH}_{4}$ フラックスの測定が可能 である。オープンパス型ガス分析計のうち最も普及 している LI-COR 社の LI-7500 は $\rho_{\mathrm{c}}, \rho_{\mathrm{v}}, p$ を同時に 測定でき, 音仮温度が測定できる超音波風速計と組 み合わせることで各種補正を適用した顕熱フラック ス $H$, 潜熱フラックス $\lambda E, \mathrm{CO}_{2}$ フラックスの算出が 可能である。以下では, LI-7500 の使用を想定し, 密 度変動補正をオープンパス型渦相関法へ適用する際 の手順と注意点を説明する。

適切な座標変換により鉛直風速 $w$ が得られている とき, オープンパス型渦相関法システムの実測デー 夕に対する密度変動補正は, 式(10)を書き改め 


$$
\begin{aligned}
\bar{\rho}_{\mathrm{d}} \overline{w^{\prime} \chi_{\mathrm{c}}^{\prime}}= & A_{\mathrm{c}}^{-1}\left(\overline{w^{\prime} \rho_{\mathrm{c}}^{\prime}}\right)_{m} \\
& +\bar{\chi}_{\mathrm{c}} A_{\mathrm{v}}^{-1}\left(\overline{w^{\prime} \rho_{\mathrm{v}}^{\prime}}\right)_{m} \\
& +\bar{\rho}_{\mathrm{c}}\left(1+\bar{\chi}_{\mathrm{v}}\right)\left[A_{\mathrm{T}}^{-1} \frac{\left(\overline{w^{\prime} T^{\prime}}\right)_{m}}{\bar{T}}-A_{\mathrm{p}}^{-1} \frac{\left(\overline{w^{\prime} p^{\prime}}\right)_{m}}{\bar{p}}\right]
\end{aligned}
$$

となる (Massman, 2004)。同様に, 地表面の水蒸気フ ラックス (蒸発散量) $E=\bar{\rho}_{\mathrm{d}} \overline{w^{\prime} \chi_{\mathrm{v}}^{\prime}}$ は,

$$
\begin{aligned}
\bar{\rho}_{\mathrm{d}} \overline{w^{\prime} \chi_{\mathrm{v}}^{\prime}}=\left(1+\bar{\chi}_{\mathrm{v}}\right) A_{\mathrm{v}}^{-1}\left(\overline{w^{\prime} \rho_{\mathrm{v}}^{\prime}}\right)_{m} \\
+\bar{\rho}_{\mathrm{v}}\left(1+\bar{\chi}_{\mathrm{v}}\right)\left[A_{\mathrm{T}}^{-1} \frac{\left(\overline{w^{\prime} T^{\prime}}\right)_{m}}{\bar{T}}-A_{\mathrm{p}}^{-1} \frac{\left(\overline{w^{\prime} p^{\prime}}\right)_{m}}{\bar{p}}\right]
\end{aligned}
$$

と書ける。ここで， $A_{x}$ は高周波あるいは低周波成分 の欠損による共分散の減少の割合を示す係数で，添 え字 $x$ は各々のスカラーを表す。例えば, $\mathrm{CO}_{2}$ の場 合, $A_{\mathrm{c}}=\left(\overline{w^{\prime} \rho_{\mathrm{c}}^{\prime}}\right)_{m} / \overline{w^{\prime} \rho_{\mathrm{c}}^{\prime}}$ で, 添え字の $m$ は超音波風速 計とオープンパス型 $\mathrm{CO}_{2} \cdot \mathrm{H}_{2} \mathrm{O}$ 分析計による実測值 を意味する。 $T$ の推定に超音波風速計が出力する音 仮温度を用いる場合， $\left(\overline{w^{\prime} T^{\prime}}\right)_{m}$ にはセンサー間の距 離(センサーセパレーション)による高周波減衰が存

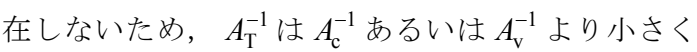
なる。したがって, 密度変動補正の適用後のフラッ クスではなく適用前の各項に周波数応答補正 $A_{x}^{-1}$ を 適用しておく必要がある。 $A_{x}$ の求め方には，(a) 既知 の伝達関数を組み合わせる方法 (e.g., Moore, 1986; Massman, 2000), (b) 周波数領域における正味の減衰 を指数関数等で近似する方法 (e.g., Aubinet et al., 2000), (c) 欠損のない周波数帯との比較によって推 定する方法 (バンドパスコバリアンス法) (e.g., Watanabe et al., 2000; Asanuma et al., 2005) が主に用い られる。方法 (a)，（b)では，実測ではなくモデル化 されたコスペクトルを用いて $A_{x}$ を求める場合が多い。 一方, 方法 (c)では, 平均化時間毎にフーリエ変換を 行い, $\left(\overline{w^{\prime} \rho_{\mathrm{c}}^{\prime}}\right)_{m}$ などの減衰したコスペクトルを $\left(\overline{w^{\prime} T^{\prime}}\right)_{m}$ のコスペクトルと一致するように欠損部分 を復元することによって $A_{x}$ を求める。用いる仮定は バンドパス周波数帯とそれより高周波側でのスカ ラ一輸送の相似性のみで, 各項の補正係数 $A_{x}^{-1}$ の不 整合が発生しにくい。また，周波数応答特性が十分 に検証されていない測器，あるいは伝達関数が想定 していないような設置状況にも有効である。4.1 で 示されたように密度変動補正を行う上で，補正係数 $A_{x}^{-1}$ の不整合に対しては最も慎重にならなければな らない。そのため, 密度変動補正の適用という観点
では方法 (c)が最も適していると思われる。ただし， フラックスが小さいときにはフーリエ変換の不確実 性が高くなり現実的ではない係数が算出される。そ のような条件では前もって作成しておいた補正係数 と風速・安定度の関係式を利用する方法もある (e.g.

Takagi et al., 2009)。

他の項についても基本的に LI-7500 の出力を用い て計算される。ただし，Webb et al. (1980)あるいは Leuning (2004) は簡便法として，式 (27) において $\left(\overline{w^{\prime} \rho_{\mathrm{v}}^{\prime}}\right)_{m}$ の代わりに $E$ を用いているが，導出の原理 にしたがえば密度変動補正を適用する前の $\left(\overline{w^{\prime} \rho_{\mathrm{v}}^{\prime}}\right)_{m}$ を用いるべきである。また，超音波風速計の $T_{\mathrm{s}}$ を用 いた場合には，水蒸気の効果を除くために

$$
\overline{w^{\prime} T^{\prime}}=\overline{w^{\prime} T_{\mathrm{s}}^{\prime}}-0.321 \bar{T} \overline{w^{\prime} s_{\mathrm{v}}^{\prime}}
$$

の補正式 (Schotanus et al., 1983; Aubinet et al., 2000) を 適用する必要があるが，湿潤空気に対する水蒸気モ ル分率 $s_{\mathrm{v}}\left(=\rho_{\mathrm{v}} / \rho_{\mathrm{m}}\right)$ のフラックス $\overline{w^{\prime} s_{\mathrm{v}}^{\prime}}$ は, 式 (28)の $\overline{w^{\prime} \chi_{\mathrm{V}}^{\prime}}$ を用いて, 例えば

$$
\overline{w^{\prime} s_{\mathrm{V}}^{\prime}}=\left(1-2 \bar{\chi}_{\mathrm{v}}\right) \overline{w^{\prime} \chi_{\mathrm{v}}^{\prime}}
$$

のように算出されるため，㛜密には，式 (29)と式 (30)を式(28)に代入し， $\overline{w^{\prime} \chi_{\mathrm{v}}^{\prime}}$ について整理した式で 評価する。水蒸気が多い条件で $\overline{w^{\prime} T^{\prime}}$ の代わりに $\overline{w^{\prime} T_{\mathrm{s}}^{\prime}}$ を用いた場合には， $\overline{w^{\prime} \chi_{\mathrm{v}}^{\prime}}$ が $2 \%$ 近く過大評価 となる。なお, $\mathrm{CO}_{2} \cdot \mathrm{H}_{2} \mathrm{O}$ 分析計 (IRGA) では $\mathrm{CO}_{2}$ と $\mathrm{H}_{2} \mathrm{O}$ がわずかに影響を及ぼし合うが (cross sensitivity), 現行の主要なモデルでは各々測器に固有の係数を用 いて内部的に補正されている。

2004 年以降, オープンパス型 $\mathrm{CO}_{2} \cdot \mathrm{H}_{2} \mathrm{O}$ 分析計の センサーヘッド部分が放射等により正負の熱源とな りフラックス推定值に影響を及ぼすいわゆる熱源問 題が広く知られるようになった (e.g., Massman, 2004; Ono et al., 2004; Amiro et al., 2006; Burba et al., 2008; Ono et al., 2008)。これは，物理的に異なる複数のセ ンサーを用いて密度変動補正を行う現在のオープン パス型渦相関法が潜在的に抱える問題でもある。LI7500 の場合, センサーヘッドは白色に塗装され消費 電力も測器全体で $10 \mathrm{~W}$ に押さえられているが，と くに低温時に，センサーヘッド表面の温度と気温の 差が大きくなり，測定パス内に追加的な熱フラック ス $\Delta \overline{w^{\prime} T^{\prime}}$ が生じる (e.g., Grelle and Burba, 2007; Burba et al., 2008)。この追加的な $\Delta \overline{w^{\prime} T^{\prime}}$ は超音波風速計で は検知されないため, 日中は $\mathrm{CO}_{2}$ フラックスを吸収 側に過大評価する。対策として, $\Delta \overline{w^{\prime} T^{\prime}}$ を小さくす るような測器または測器配置とすること，あるいは $\Delta \overline{w^{\prime} T^{\prime}}$ を実測または推定し式(27)の $\left(\overline{w^{\prime} T^{\prime}}\right)_{m}$ に加え ることが考えられる。前者は, センサーを小型化し 
たり，放射の影響を小さくするために表面反射率を 高めたり, あるいは射出率を小さくしたりすること が有効である。密度変動補正を厳格に適用するとい う観点では, オープンパス型渦相関法と超音波風速 計のセンサー距離を縮めることも有効であるが(例え ば, Campbell Scientific 社から発売された IRGASON), $\Delta \overline{w^{\prime} T^{\prime}}$ が光学空近傍で局所的に発生している可能性 もあるため熱源問題に対しての効果は未知数である (Ono et al., 2009)。また，流れを乱す影響も懸念され る。後者については, 細線熱電対あるいは細線白金 抵抗温度計を用いた実測の例が発表されているが, いずれもセンサーの強度に問題があり長期連続測定 には向いていない。 $\overline{\Delta w^{\prime} T^{\prime}}$ を推定するモデルは, 現 時点では Burba et al. (2008) と Heusinkveld et al. (2008)が提案している。Burba et al. (2008) は, 過去 のデータにも適用できるように一般的な気象要素か ら $\Delta \overline{w^{\prime} T^{\prime}}$ の推定を試みているが，センサーヘッド表 面の温度と気温との差を気象要素の重回帰式で表す など大胆な簡略化がなされている。一方,

Heusinkveld et al. (2008) は, センサーヘッドの熱収 支に基づいて算出した表面温度を用いて $\Delta \overline{w^{\prime} T^{\prime}}$ を推 定しており，Burba et al. (2008)に比べて精度が高い と思われる。両推定モデルともセンサーヘッドで発 生した熱がすべて測定パス内を通過することが仮定 されているが, 測定パスを通過する熱の割合が風速 によって大きく変動するという報告もある (Ono et al. 2009)。また, 適用できるセンサーの設置角度にも制 限がある。いずれにせよ，4.1 で示されたように， 地表面 $\mathrm{CO}_{2}$ フラックスが小さい雪面等では密度変動 補正に関わる誤差が大幅に増大寸るため, これらの 補正はとりわけ慎重に適用する必要がある。

近年, LI-7500について, 光学空に付着した污れに よって $\rho_{\mathrm{c}}$ と $\rho_{\mathrm{v}}$ の出力の絶対值が $10 \%$ 以上変化する現 象が報告されており (Serrano-Ortiz et al., 2008; Prytherch et al., 2010), この值を密度変動補正の $\bar{\rho}_{\mathrm{v}}$, $\bar{\rho}_{\mathrm{c}}$ に用いる場合は注意を要する。LI-7500を含むほ ぼすべてのオープンパス型 $\mathrm{CO}_{2} \cdot \mathrm{H}_{2} \mathrm{O}$ 分析計は, 同 じ測定パスで分子の赤外線吸収帯と非吸収帯の光量 を測定しその違いから密度の絶対值を算出している が, 両波長带は近接しているため光学空の污れは通 常打ち消される。しかし, 両波長帯で吸収率が大き く異なる付着物の場合, 絶対值の測定に影響を及ぼ しうる。Serrano-Ortiz et al. (2008) は, 乾燥地域での 測定から, 鉱物由来の付着物でそのような現象が生 じたこと，その影響が LI-7500 が採用している波長 では $\rho_{\mathrm{c}}$ が過小評価， $\rho_{\mathrm{v}}$ が過大評価となること，した がって別の温湿度センサーの出力と比較することで $\bar{\rho}_{\mathrm{c}}$ と $\bar{\rho}_{\mathrm{v}}$ の両方が補正されうることを示した。
Prytherch et al. (2010) も海洋で類似の測定結果を得て いる。原理的には, Serrano-Ortiz et al. (2008)の方法 で補正可能と思われるが，付着物によって両者の関 係が変化する可能性は十分にあるためサイト毎に経 験式を作成する必要がある。一方, Serrano-Ortiz et al. (2008)の実験ではこの影響はスパン(検量線の傾き) には見られなかったと明記されているが，海洋では， 連続測定中に海塩粒子の付着が原因と思われる絶対 值の低下とともに $\rho_{\mathrm{c}}$ の変動が増大寸る現象も確認さ れている(Tsukamoto and Kondo, 2011)。こちらは共 分散に基づいてフラックスを算出する渦相関法の根 幹に関わるため, クローズドパス型との比較観測な どに基づいた実態の解明が急がれる。いずれにせよ, 現時点では, 光学空を定期的に清掃し, 可能であれ ば絶対值が安定して測定できる湿度センサー等を併 用することが取り得る唯一の対策である。光学空の 污れについては, 海面あるいは乾燥地のように元々 $\mathrm{CO}_{2}$ フラックスが小さい場所でとくに生じやすいと 考えられ，このようなサイトでは密度変動補正の適 用にはより一層の注意が必要である。

現在市販されている唯一のオープンパス型 $\mathrm{CH}_{4}$ 分 析計 (LI-7700; LI-COR)についても，上記の問題はほ ぼすべて当てはまる。まず測定システムとしては, $\overline{w^{\prime} \rho_{\mathrm{v}}^{\prime}}$ を測定するために LI-7500 等を併用する必要が ある。LI-7500 等を用いて $\overline{w^{\prime} \rho_{\mathrm{v}}^{\prime}}$ を同時に測定し, 式 (28), 式(29), 式(30) を用いて密度変動補正を行う。 LI-7700 は測定パスが他の測器に比べ長く $(50 \mathrm{~cm})$ 断 面積も大きいため, 周波数応答補正は, 不整合が生 じないように LI-7500 の場合以上に慎重に行う必要 がある。LI-7500については, 近年改良が加えられ, センサーヘッド内部のチョッパー収納部の温度を 2 段階 $\left(5^{\circ} \mathrm{C}\right.$ と $\left.30^{\circ} \mathrm{C}\right)$ に設定できるものが市販化された (LI-7500A)。この追加機能は, 消費電力と熱源問題 の両面において, 中高緯度域の冬季の測定では有用 である。

\subsection{2 クローズドパス型渦相関法への適用}

クローズドパス型渦相関法は, 超音波風速計の測 定パス近傍に設置した吸入口からチューブとポンプ を用いて空気を引き込み, タワー基部等に設置した クローズドパス型分析計で分析した濃度を用いてフ ラックスを算出する方法で, 近年の技術的な進歩に より, 現在では $\mathrm{H}_{2} \mathrm{O}, \mathrm{CO}_{2}$ のほか, $\mathrm{CH}_{4}, \mathrm{~N}_{2} \mathrm{O}$, さら には安定同位体比の測定も可能となっている。 チューブ内での高周波減衰が場合によっては大きく なるが， $\mathrm{CO}_{2}$ に関しては，安定した分析計が 1990 年 頃から市販化されていたため, 商用電源が得られる 森林のサイトを中心に現在でも広く利用されている (Mizoguchi et al., 2009)。クローズドパス型 $\mathrm{CO}_{2}$ ・ 
$\mathrm{H}_{2} \mathrm{O}$ 分析計も原理的には赤外線吸光度から $\mathrm{CO}_{2}$ と $\mathrm{H}_{2} \mathrm{O}$ 分子数密度を測定するものであるが, オープン パス型と異なり, 測定セルの気圧と気温の変動, あ るいはそれに準ずるものを内部で測定できるため, 実用上問題のない精度で混合比 $\chi_{\mathrm{c}}, \chi_{\mathrm{v}}$ を求めること が可能である(Ibrom et al., 2007)。新たに市販された モデル(LI-7200)は，オープンパス型の LI-7500 が ベースとなっているため小型で, チューブ長を数 10 $\mathrm{cm}$ 程度まで短縮でき, 混合比への変換も問題ない (Nakai et al., 2011; Burba et al., 2012)。したがって, $\mathrm{CO}_{2}, \mathrm{H}_{2} \mathrm{O}$ フラックスをクローズドパス型渦相関法 で測定する場合, 基本的に密度変動補正を適用する 必要がない。しかし，これらの大気成分以外では， 場合によっては必要となるため, クローズドパス型 渦相関法に密度変動補正を適用する際のポイントを 説明する。

クローズドパス型渦相関法では, 地表面 $\mathrm{CO}_{2}$ フ ラックスは, オープンパス型(式 27) とほぼ同様に

$$
\begin{aligned}
\bar{\rho}_{\mathrm{d}} \overline{w^{\prime} \chi_{\mathrm{c}}^{\prime}}= & A_{\mathrm{c}}^{-1}\left(\overline{w^{\prime} \rho_{\mathrm{c}}^{\prime}}\right)_{m}+\bar{\chi}_{\mathrm{c}}\left(A_{\mathrm{v}}\right)_{c}^{-1}\left(\overline{w^{\prime} \rho_{\mathrm{v}}^{\prime}}\right)_{m} \\
& +\bar{\rho}_{\mathrm{c}}\left(1+\bar{\chi}_{\mathrm{v}}\right)\left[\left(A_{\mathrm{T}}\right)_{c}^{-1} \frac{\left(\overline{w^{\prime} T^{\prime}}\right)_{m}}{\bar{T}}-\left(A_{\mathrm{p}}\right)_{c}^{-1} \frac{\left(\overline{w^{\prime} p^{\prime}}\right)_{m}}{\bar{p}}\right]
\end{aligned}
$$

と表せる。オープンパス型と異なるのは, $\left(\overline{w^{\prime} \rho_{\mathrm{c}}^{\prime}}\right)_{m}$ 以外の共分散に掛かる周波数応答補正が $\left(A_{\mathrm{v}}\right)_{c}^{-1}$, $\left(A_{\mathrm{T}}\right)_{c}^{-1},\left(A_{\mathrm{p}}\right)_{c}^{-1}$ となっている点である。ここで, $\left(A_{\mathrm{V}}\right)_{c}=\left(\overline{w^{\prime} \rho_{\mathrm{V}}^{\prime}}\right)_{m} /\left(\overline{w^{\prime} \rho_{\mathrm{v}}^{\prime}}\right)_{c}, \quad\left(A_{\mathrm{T}}\right)_{c}=\left(\overline{w^{\prime} T^{\prime}}\right)_{m} /\left(\overline{w^{\prime} T^{\prime}}\right)_{c}$, $\left(A_{\mathrm{p}}\right)_{c}=\left(\overline{w^{\prime} p^{\prime}}\right)_{m} /\left(\overline{w^{\prime} p^{\prime}}\right)_{c}$ である。( $\left(\overline{w^{\prime} \rho_{\mathrm{v}}^{\prime}}\right)_{c}, \quad\left(\overline{w^{\prime} T^{\prime}}\right)_{c}$ $\left(\overline{w^{\prime} p^{\prime}}\right)_{c}$ は, クローズドパス型 $\mathrm{CO}_{2} \cdot \mathrm{H}_{2} \mathrm{O}$ 分析計の 測定セルに入る直前の空気の $\mathrm{H}_{2} \mathrm{O}$, 温度, 気圧の変 動に基づく共分散である。クローズドパス型では, クローズドパス型 $\mathrm{CO}_{2} \cdot \mathrm{H}_{2} \mathrm{O}$ 分析計の測定セル(オー プンパス型の測定パスに相当)が有限の体積を持つこ とのほか，空気がチューブ内を移動することによっ ても変動の減衰が生じる。これは $\rho_{\mathrm{c}}, \rho_{\mathrm{v}}, T, p$ のす べてに当てはまるが, 密度変動補正では, $\rho_{\mathrm{v}}, T, p$ については, チューブ内での減衰は補正する必要が ない。これは, 密度変動補正の原則が $\mathrm{CO}_{2}$ 密度変動 と混合比変動の関係式(式 2)であり, クローズドパ ス型 $\mathrm{CO}_{2} \cdot \mathrm{H}_{2} \mathrm{O}$ 分析計の測定セル直前の $\rho_{\mathrm{c}}^{\prime}$ に影響を 及ぼした $\bar{\chi}_{\mathrm{c}} \rho_{\mathrm{d}}^{\prime}$ のみ取り除けばよいためである。した がって， $A_{\mathrm{c}}^{-1}$ はチューブによる減衰まで考慮する必 要があるが, $\left(\mathrm{A}_{\mathrm{v}}\right)_{c}^{-1},\left(\mathrm{~A}_{\mathrm{T}}\right)_{c}^{-1},\left(\mathrm{~A}_{\mathrm{p}}\right)_{c}^{-1}$ は, 測定セル の体積平均の効果と信号処理に関わる減衰のみ考慮 すればよい(Massman, 2004; Ibrom et al., 2007)。同様 の理由で, 平均值 $\bar{\rho}_{\mathrm{c}}, \bar{T}, \bar{p}$ は, 大気ではなく, 測定セル内での值を用いる。ただし, 測定セル内の
温度あるいは気圧が吸入口と大きく異なっている場 合は，式 (31) の右辺に $\bar{\rho}_{\mathrm{d}} /\left(\bar{\rho}_{\mathrm{d}}\right)_{c}$ を乗じる (Leuning and Moncrieff, 1990)。ここで， $\left(\bar{\rho}_{\mathrm{d}}\right)_{c}$ は測定セル内 の温度と気圧から求めた乾燥空気密度である。とこ ろで，式(31)では，チューブによる遅れ時間，すな わち空気がチューブ内を移動することで生じる $w$ 信 号との時系列のずれがあらかじめ修正されているこ とが暗に仮定されている(周波数応答補正に遅れ時間 による減衰も含める場合もある)。各々について, 平 均化時間毎に $w\left(\right.$ あるい $\left.T_{\mathrm{s}}\right)$ との相互相関が最大に なるように時系列をずらすという方法が一般に取ら れている(e.g., Moncrieff et al., 1997)。これは, 引き 込む空気の相対湿度によって遅れ時間が変化するこ と, その程度が $\rho_{\mathrm{c}}$ と $\rho_{\mathrm{v}}$ で異なることによる (Ibrom et al., 2007)。しかし, 密度変動補正を適用する場合は, $\rho_{\mathrm{c}}^{\prime}$ を生じさせた $\rho_{\mathrm{v}}^{\prime}$ が問題となるゆえ, $\left(\overline{w^{\prime} \rho_{\mathrm{v}}^{\prime}}\right)_{m}$ の 遅れ時間は, $\left(\overline{w^{\prime} \rho_{c}^{\prime}}\right)_{m}$ が最大になるときのものでな ければならない(Ibrom et al., 2007)。( $\left.\overline{w^{\prime} T^{\prime}}\right)_{c}$ と $\left(\overline{w^{\prime} p^{\prime}}\right)_{c}$ については, 実際の密度変動補正では適用 されていない場合が多かったが (Leuning and Judd, 1996)，条件によっては無視できなことが明らかに なってきたため (Leuning, 2004; Massman, 2004; Burba et al., 2012)，T, p ともに生データを記録し共分散を 評価できるようしておくことが望ましい。なお，水 蒸気フラックス $E\left(=\bar{\rho}_{\mathrm{d}} \overline{w^{\prime} \chi_{\mathrm{v}}^{\prime}}\right)$ についは,

$$
\begin{aligned}
\bar{\rho}_{\mathrm{d}} \overline{w^{\prime} \chi_{\mathrm{v}}^{\prime}}= & {\left[A_{\mathrm{v}}^{-1}+\bar{\chi}_{\mathrm{v}}\left(A_{\mathrm{v}}\right)_{c}^{-1}\right]\left(\overline{w^{\prime} \rho_{\mathrm{v}}^{\prime}}\right)_{m} } \\
& +\bar{\rho}_{\mathrm{v}}\left(1+\bar{\chi}_{\mathrm{v}}\right)\left[\left(A_{\mathrm{T}}\right)_{c}^{-1} \frac{\left(\overline{w^{\prime} T^{\prime}}\right)_{m}}{\bar{T}}-\left(A_{\mathrm{p}}\right)_{c}^{-1} \frac{\left(\overline{w^{\prime} p^{\prime}}\right)_{m}}{\bar{p}}\right]
\end{aligned}
$$

となる。

いずれにしても, 現在渦相関法に用いられるク ローズドパス型 $\mathrm{CO}_{2} \cdot \mathrm{H}_{2} \mathrm{O}$ 分析計については生デー 夕の段階で実用上問題のない精度で混合比に変換で きるため, 上述の密度変動補正(式 31，32) は必要な い。また，例えば， $\mathrm{H}_{2} \mathrm{O}$ の同時測定ができないク ローズドパス型 $\mathrm{CH}_{4}$ 分析計を除湿を行わない渦相関 法システムで使用した場合でも，クローズドパス型 $\mathrm{CH}_{4}$ 分析計とクローズドパス型 $\mathrm{CO}_{2} \cdot \mathrm{H}_{2} \mathrm{O}$ 分析計が 測定ラインの中で一体と見なせる配置であれば，密 度変動補正を避け，混合比の換算を試みた方がよい と思われる。一方, このようなシステムにおいて, クローズドパス型 $\mathrm{CO}_{2} \cdot \mathrm{H}_{2} \mathrm{O}$ 分析計の代わりに LI7500 等のオープンパス型 $\mathrm{CO}_{2} \cdot \mathrm{H}_{2} \mathrm{O}$ 分析計を用いる ことは, $\left(A_{\mathrm{v}}\right)_{c}^{-1}$ の評価が著しく困難なため, 勧めら れない。

生データの段階で混合比が算出できる通常のク 
ローズドパス型システムについては,

$$
\begin{aligned}
& \bar{\rho}_{\mathrm{d}} \overline{w^{\prime} \chi_{\mathrm{c}}^{\prime}}=\bar{\rho}_{\mathrm{d}} A_{\mathrm{c}}^{-1}\left(\overline{w^{\prime} \chi_{\mathrm{c}}^{\prime}}\right)_{m} \\
& \bar{\rho}_{\mathrm{d}} \overline{w^{\prime} \chi_{\mathrm{v}}^{\prime}}=\bar{\rho}_{\mathrm{d}} A_{\mathrm{v}}^{-1}\left(\overline{w^{\prime} \chi_{\mathrm{v}}^{\prime}}\right)_{m}
\end{aligned}
$$

を用いて地表面 $\mathrm{CO}_{2} \cdot \mathrm{H}_{2} \mathrm{O}$ フラックスを推定する。 $A_{\mathrm{c}}^{-1} ， A_{\mathrm{v}}^{-1}$ は，4.3.1 で紹介した (a)，（b)，（c)のい ずれかを用いて推定する。先に遅れ時間を修正する 場合は， $\chi_{\mathrm{c}}, \chi_{\mathrm{v}}$ の時系列を使って $w$ (あるいは $T_{\mathrm{s}}$ ) と の相互相関を各々計算する。LI-7200 は測器内部で演 算を行い $\chi_{\mathrm{c}}, \chi_{\mathrm{v}}$ を出力可能である。一方, LI-6262 お よびLI-7000 の出力は, $\mathrm{CO}_{2}, \mathrm{H}_{2} \mathrm{O}$ ともに湿潤空気に 対するモル分率であるため (Ibrom et al., 2007), $\chi_{\mathrm{c}}=s_{\mathrm{c}} /\left[1+s_{\mathrm{v}} /\left(1-s_{\mathrm{v}}\right)\right], \chi_{\mathrm{v}}=S_{\mathrm{v}} /\left(1-s_{\mathrm{v}}\right)$ を用いて混合比に変 換したあと式(33), 式(34)によりフラックスを算出 する。ここで, $s_{\mathrm{c}}\left(=\rho_{\mathrm{c}} / \rho_{\mathrm{m}}\right)$ は湿潤空気に対する $\mathrm{CO}_{2}$ モ ル分率である。なお，LI-6262 は，設定を変更するこ とで $\mathrm{CO}_{2}$ についてのみ測器内部で演算した $\chi_{\mathrm{c}}$ を出力 させることが可能である(Ibrom et al., 2007)。

\section{5. おわりに}

渦相関法に用いられる密度変動補正の本質は極め てシンプルで, 一言で表せば, 乾燥空気の質量(分子 数) 保存則に基づいた共分散どうしの演算により密度 フラックスを混合比フラックスに変換するための操 作ということになる。本稿は, その本質の理解の一 助となることを目的に, 導出方法を類型化し各々の 論点を整理した。さらに，オープンパス型とクロー ズドパス型に分けて実際の適用方法と留意点につい て議論した。密度変動補正は共分散の和として表さ れるため, 地表面 $\mathrm{CO}_{2}$ フラックスに対して補正項が 大きくなりやすい冬季の裸地, 雪面, あるいは絶対 的に $\mathrm{CO}_{2}$ フラックスが小さい海面では, 密度変動補 正の精度が著しく低下する恐れがある。ただし, ク ローズドパス型は，高周波の減衰は大きいが，生 データの段階で実用上問題のない精度で混合比が得 られるため, そのような条件でもある程度の精度が 保てると思われる。密度変動補正, および生データ での混合比変換のいずれの場合も, 複数のセン サー・測器を用いるため, 各々の応答特性を十分に 把握し, 整合性のある周波数応答補正を行う必要が ある。現時点で最も懸念されることは，オープンパ ス型ガス分析計の光学密の污れが密度の絶対值測定 に及ぼす影響である。密度変動補正では, 密度, 混 合比, 気温, 気圧の絶対值が必要であるが，そのう ち $\mathrm{CO}_{2}$ 密度は補正項に直接掛かるため影響が大きい。 変動 $($ スパン $)$ への影響も含めて, まずは知見の蓄積 が急務である。オープンパス型 $\mathrm{CO}_{2} \cdot \mathrm{H}_{2} \mathrm{O}$ 分析計の
熱源問題は，影響の程度がおおよそ把握されつつあ るが, 補正モデルの開発が遅れている。数值流体力 学モデル等を利用することで, さまざまな設置角 度・方位に対応した補正モデルが確立される可能性 がある。 $\mathrm{CO}_{2}, \mathrm{H}_{2} \mathrm{O}$ 以外の大気成分への適用も含め 当面は渦相関法による生態系一大気間フラックスの 測定は関連する様々な分野で活用されることが予想 され, 密度変動補正を含めた地表面フラックス推定 のためのフレームワークについて理解を深めること は今後も重要であろう。一方, 本稿で明らかになっ たように密度変動補正の精度には限界があるため, 今後開発されるガス分析計は，混合比の利用を前提 としたものとなることを期待したい。

\section{謝辞}

本稿をまとめるに当たり，宮田 明博士には示唆に 富むアドバイスを多数頂戴しました。また，間野正 美博士，滝本貴弘博士には，原稿を校閲いただきま した。ここに記して御礼申し上げます。

\section{引用文献}

Amiro, B., Orchansky, A., and Sass, A., 2006: A perspective on carbon dioxide flux measurements using an open-path infrared gas analyzer in cold environments. Proceedings of the American Meteorological Society's 27th Conference on Agricultural and Forest Meteorology, P4. 7.

Asanuma, J., Ishikawa, H., Tamagawa, I., Ma, Y., Hayashi, T., Qi, Y., and Wang, J., 2005: Application of the band-pass covariance technique to portable flux measurements over the Tibetan Plateau. Water Resour. Res., 41, W09407.

Aubinet, M., Grelle, A., Ibrom, A., Rannik, U., Moncrieff, J., Foken, T., Kowalski, A. S., Martin, P. H., Berbigier, P., Bernhofer, C., Clement, R., Elbers, J., Granier, A., Grünwald, T., Morgenstern, K., Pilegaard, K., Rebmann, C., Snijders, W., Valentini, R., and Vesala, T., 2000: Estimates of the annual net carbon and water exchange of forests: The EUROFLUX methodology. Adv. Ecol. Res., 30, 113-175.

Bakan, S., 1978: Note on the eddy correlation method for $\mathrm{CO}_{2}$ flux measurements. Boundary-Layer Meteorol., 14, 597-600.

Burba, G. G., McDermitt, D. K., Grelle, A., Anderson, D. J., and Xu, L., 2008: Addressing the influence of instrument surface heat exchange on the measurements of $\mathrm{CO}_{2}$ flux from open-path gas analyzers. Global Change Biol., 14, 1854-1876. 
Burba, G., Schmidt, A., Scott, R., Nakai, T., Kathilankal, J., Fratini, G., Hanson, C., Law, B., McDermitt, D., Eckles, R., Furtaw, M., and Velgersdyk, M., 2012: Calculating $\mathrm{CO}_{2}$ and $\mathrm{H}_{2} \mathrm{O}$ eddy covariance fluxes from an enclosed gas analyzer using an instantaneous mixing ratio. Global Change Biol., 18, 385-399.

Desjardins, R. L., and Lemon, E. R., 1974: Limitations of an eddy-correlation technique for the determination of the carbon dioxide and sensible heat fluxes. BoundaryLayer Meteorol., 5, 475-488.

Detto, M., and Katul, G. G., 2007: Simplified expressions for adjusting higherorder turbulent statistics obtained from open path gas analyzers. Boundary-Layer Meteorol., 122, 205-216.

Fairall, C., Hare, J., Edson, J., and McGillis, W., 2000: Parameterization and micrometeorological measurement of air-sea gas transfer. Boundary-Layer Meteorol., 96, 63-106.

Finkelstein, P. L., and Sims, P. F., 2001: Sampling error in eddy correlation flux measurements. J. Geophys. Res., 106, 3503-3509.

Foken, T., 2008: The energy balance closure problem: an overview. Ecol. Appl., 18, 1351-1367.

Foken, T., Aubinet, M., Finnigan, J. J., Leclerc, M. Y., Mauder, M., and Paw U, K. T., 2011: Results of a panel discussion about the energy balance closure correction for trace gases. Bull. Am. Meteorol. Soc., 92, ES13ES18.

Fuehrer, P. L., and Friehe, C. A., 2002: Flux corrections revisited. Boundary-Layer Meteorol., 102, 415-457.

Grelle, A., and Burba, G., 2007: Fine-wire thermometer to correct $\mathrm{CO}_{2}$ fluxes by open-path analyzers for artificial density fluctuations. Agric. For. Meteorol., 147, 48-57.

Haslwanter, A., Hammerle, A., and Wohlfahrt, G., 2009: Open-path vs. closed-path eddy covariance measurements of the net ecosystem carbon dioxide and water vapour exchange: A long-term perspective. Agric. For. Meteorol., 149, 291-302.

Heusinkveld, B. G., Jacobs, A. F. G., and Holtslag, A. A. M., 2008: Effect of open-path gas analyzer wetness on eddy covariance flux measurements: A proposed solution. Agric. For. Meteorol., 148, 1563-1573.

Hirata, R., Saigusa, N., Yamamoto, S., Ohtani, Y., Ide, R., Asanuma, J., Gamo, M., Hirano, T., Kondo, H., Kosugi, Y., Li, S. -G., Nakai, Y., Takagi, K., Tani, M., and Wang, H., 2008: Spatial distribution of carbon balance in forest ecosystems across East Asia. Agric. For. Meteorol., 148, 762-775.

Ibrom, A., Dellwik, E., Larsen, S., and Pilegaard, K.,
2007: On the use of the Webb-Pearman-Leuning theory for closed-path eddy correlation measurements. Tellus $B, \mathbf{5 9}, 937-946$.

Jones, E. P., and Smith, S. D., 1977: A first measurement of sea-air $\mathrm{CO}_{2}$ flux by eddy correlation. J. Geophys. Res., 82, 5990-5992.

Jones, E. P., and Smith, S. D., 1978: The air density correction to eddy flux measurements. Boundary-Layer Meteorol., 15, 357-360.

Kondo, F., and Tsukamoto, O., 2008: Evaluation of Webb correction on $\mathrm{CO}_{2}$ flux by eddy covariance technique using open-path gas analyzer over asphalt surface. $J$. Agric. Meteorol., 64, 1-8.

Kowalski, A. S., 2006a: Comment on "An alternative approach for $\mathrm{CO}_{2}$ flux correction caused by heat and water vapour transfer" by Liu. Boundary-Layer Meteorol., 120, 353-355.

Kowalski, A. S., 2006b: Further comment on "Reply to the comment by Kowalski on 'An alternative approach for $\mathrm{CO}_{2}$ flux correction caused by heat and water vapour transfer' by Liu”. Boundary-Layer Meteorol., 120, 365-366.

Kowalski, A. S., and Serrano-Ortiz, P., 2007: On the relationship between the eddy covariance, the turbulent flux, and surface exchange for a trace gas such as $\mathrm{CO}_{2}$. Boundary-Layer Meteorol., 124, 129-141.

Lee, X., and Massman, W., 2011: A perspective on thirty years of the Webb, Pearman and Leuning density corrections. Boundary-Layer Meteorol., 139, 37-59.

Leuning, R., 2004: Measurements of trace gas fluxes in the atmosphere using eddy covariance, WPL corrections revisited. In Handbook of Micrometeorology, A Guide for Surface Flux Measurements and Analysis (ed. by Lee, X., Massman, W., and Law, B.). Kluwer Academic Publishers, Dordrecht, pp. 119-132.

Leuning, R., 2007: The correct form of the Webb, Pearman and Leuning equation for eddy fluxes of trace gases in steady and non-steady state, horizontally homogeneous flows. Boundary-Layer Meteorol., 123, 263-267.

Leuning, R., and Judd, M. J., 1996: The relative merits of open- and closed-path analysers for measurement of eddy fluxes. Global Change Biol., 2, 241-253.

Leuning, R., and Moncrieff, J., 1990: Eddy-covariance $\mathrm{CO}_{2}$ flux measurements using open- and closed-path $\mathrm{CO}_{2}$ analysers: Corrections for analyser water-vapour sensitivity and damping of fluctuations in air sampling tubes. Boundary-Layer Meteorol., 53, 63-76.

Liu, H. P., 2005: An alternative approach for $\mathrm{CO}_{2}$ flux correction caused by heat and water vapour transfer. 
Boundary-Layer Meteorol., 115, 151-168.

Liu, H. P., 2006: Reply to the comment by Kowalski on "An alternative approach for $\mathrm{CO}_{2}$ flux correction caused by heat and water vapour transfer". BoundaryLayer Meteorol., 120, 357-363.

Liu, H. P., Randerson, J. T., Lindfors, J., Massman, W. J., and Foken, T., 2006: Consequences of incomplete surface energy balance closure for $\mathrm{CO}_{2}$ fluxes from openpath $\mathrm{CO}_{2} / \mathrm{H}_{2} \mathrm{O}$ infrared gas analysers. Boundary-Layer Meteorol., 120, 65-85.

Lloyd, C. R., 1995: The effect of heterogeneous terrain on micrometeorological flux measurements: a case study from HAPEX-SAHEL. Agric. For. Meteorol., 73, 209216.

Massman, W., 2000: A simple method for estimating frequency response corrections for eddy covariance systems. Agric. For. Meteorol., 104, 185-198.

Massman, W., 2004: Concerning the measurement of atmospheric trace gas fluxes with open- and closed-path eddy covariance system: The WPL terms and spectral attenuation. In Handbook of Micrometeorology, A Guide for Surface Flux Measurements and Analysis (ed. by Lee, X., Massman, W., and Law, B.). Kluwer Academic Publishers, Dordrecht, pp. 133-160.

Massman, W., and Lee, X., 2002: Eddy covariance flux corrections and uncertainties in long-term studies of carbon and energy exchanges. Agric. For. Meteorol., 113, 121-144.

Massman, W., and Tuovinen, J. -P., 2006: An analysis and implications of alternative methods of deriving the density (WPL) terms for eddy covariance flux measurements. Boundary-Layer Meteorol., 121, 221-227.

McGillis, W., Edson, J., Hare, J., and Fairall, C., 2001: Direct covariance air-sea $\mathrm{CO}_{2}$ fluxes. J. Geophys. Res., 106, 16729-16745.

Mizoguchi, Y., Miyata, A., Ohtani, Y., Hirata, R., and Yuta, S., 2009: A review of tower flux observation sites in Asia. J. For. Res., 14, 1-9.

Moncrieff, J., Clement, R., Finnigan, J., and Meyers, T., 2004: Averaging, detrending, and filtering of eddy covariance time series. In Handbook of Micrometeorology, A Guide for Surface Flux Measurements and Analysis (ed. by Lee, X., Massman, W., and Law, B.). Kluwer Academic Publishers, Dordrecht, pp. 7-31.

Moncrieff, J. B., Massheder, J. M., de Bruin, H., Elbers, J., Friborg, T., Heusinkveld, B., Kabat, P., Scott, S., Soegaard, H., and Verhoef, A., 1997: A system to measure surface fluxes of momentum, sensible heat, water vapour and carbon dioxide. J. Hydrol., 188-189, 589-611.
Moore, C. J., 1986: Frequency response corrections for eddy correlation systems. Boundary-Layer Meteorol., 37, 17-35.

Nakai, T., Iwata, H., and Harazono, Y., 2011: Importance of mixing ratio for a long-term $\mathrm{CO}_{2}$ flux measurement with a closed-path system. Tellus B, 63, 302-308.

Ohkubo, S., Kosugi, Y., Takanashi, S., Mitani, T., and Tani, M., 2007: Comparison of the eddy covariance and automated closed chamber methods for evaluating nocturnal $\mathrm{CO}_{2}$ exchange in a Japanese cypress forest. Agric. For. Meteorol., 142, 50-65.

Ohta, T., Maximov, T., Dolman, A., Nakai, T., van der Molen, M., Kononov, A., Maximov, A., Hiyama, T., Iijima, Y., Moors, E., Tanaka, H., Toba, T., and Yabuki, H., 2008: Interannual variation of water balance and summer evapotranspiration in an eastern Siberian larch forest over a 7-year period (1998-2006). Agric. For. Meteorol., 148, 1941-1953.

Ono, K., Hirata, R., Mano, M., Miyata, A., Saigusa, N., and Inoue, Y., 2007: Systematic differences in $\mathrm{CO}_{2}$ fluxes measured by open- and closed-path eddy covariance systems: Influence of air density fluctuations resulting from temperature and water vapor transfer. $J$. Agric. Meteorol., 63, 139-155.

Ono, K., Mano, M., Hirata, R., and Miyata, A., 2009: A validation study of the practical corrections for sensor heating at open-path surfaces using computational fluid dynamics. Proceedings of AsiaFlux Workshop 2009, 92.

Ono, K., Miyata, A., and Yamada, T., 2008: Apparent downward $\mathrm{CO}_{2}$ flux observed with open-path eddy covariance over a non-vegetated surface. Theor. Appl. Climatol., 92, 195-208.

Ono, K., Miyata, A., Yamada, T., Nagai, H., Yoshikoshi, H., Mano, M., and Saito, M., 2004: Downward $\mathrm{CO}_{2}$ flux observed over a bare field by the eddy covariance method using an open-path infrared gas analyzer. Proceedings of American Geophysical Union 2004 Fall Meeting, B51C-0965.

Paw U, K. T., Baldocchi, D. D., Meyers, T. P., and Wilson, K. B., 2000: Correction of eddy-covariance measurements incorporating both advective effects and density fluxes. Boundary-Layer Meteorol., 97, 487-511.

Prytherch, J., Yelland, M., Pascal, R., Moat, B., Skjelvan, I., and Neill, C., 2010: Direct measurements of the $\mathrm{CO}_{2}$ flux over the ocean: Development of a novel method. Geophys. Res. Lett., 37, L03607.

Saigusa, N., Yamamoto, S., Hirata, R., Ohtani, Y., Ide, R., Asanuma, J., Gamo, M., Hirano, T., Kondo, H., Kosugi, Y., Li, S. -G., Nakai, Y., Takagi, K., Tani, M., and 
Wang, H., 2008: Temporal and spatial variations in the seasonal patterns of $\mathrm{CO}_{2}$ flux in boreal, temperate, and tropical forests in East Asia. Agric. For. Meteorol., 148, 700-713.

Schotanus, P., Nieuwstadt, F. T. M., and De Bruin, H. A. R., 1983: Temperature measurement with a sonic anemometer and its application to heat and moisture fluxes. Boundary-Layer Meteorol., 26, 81-93.

Serrano-Ortiz, P., Kowalski, A. S., Domingo, F., Ruiz, B., and Alados-Arboledas, L., 2008: Consequences of uncertainties in $\mathrm{CO}_{2}$ density for estimating net ecosystem $\mathrm{CO}_{2}$ exchange by open-path eddy covariance. Boundary-Layer Meteorol., 126, 209-218.

Smith, S. D., and Jones, E. P., 1979: Dry-air boundary conditions for correction of eddy flux measurements. Boundary-Layer Meteorol., 17, 375-379.

Suyker, A. E., and Verma, S. B., 1993: Eddy correlation measurement of $\mathrm{CO}_{2}$ flux using a closed-path sensor: Theory and field tests against an open-path sensor. Boundary-Layer Meteorol., 64, 391-407.

Takagi, K., Fukuzawa, K., Liang, N., Kayama, M., Nomura, M., Hojyo, H., Sugata, S., Shibata, H., Fukazawa, T., Takahashi, Y., Nakaji, T., Oguma, H., Mano, M., Akibayashi, Y., Murayama, T., Koike, T., Sasa, K., and Fujinuma, Y., 2009: Change in $\mathrm{CO}_{2}$ balance under a series of forestry activities in a cool-temperate mixed forest with dense undergrowth. Global Change Biol., 15,
$1275-1288$

Tsukamoto, O., and Kondo, F., 2011: Accurate measurement of air-sea $\mathrm{CO}_{2}$ flux with open-path eddy-covariance. In Gas Transfer at Water Surfaces 2010 (ed. by Komori, S., McGillis, W., and Kurose, R.). Kyoto University Press, Kyoto, pp. 485-495.

Twine, T. E., Kustas, W. P., Norman, J. M., Cook, D. R., Houser, P. R., Meyers, T. P., Prueger, J. H., Starks, P. J., and Wesely, M. L., 2000: Correcting eddy-covariance flux underestimates over a grassland . Agric. For. Meteorol., 103, 279-300.

Watanabe, T., Yamanoi, K., and Yasuda, Y., 2000: Testing of the bandpass eddy covariance method for a longterm measurement of water vapour flux over a forest. Boundary-Layer Meteorol., 96, 473-491.

Webb, E. K., and Pearman, G. I., 1977: Correction of $\mathrm{CO}_{2}$ transfer measurements for the effect of water vapor transfer. In Second Australasian Conference on Heat and Mass Transfer (ed. by Bilger, R. W.). The University of Sydney, Sydney, pp. 469-476.

Webb, E. K., Pearman, G. I., and Leuning, R., 1980: Correction of flux measurements for density effects due to heat and water-vapor transfer. Q. J. R. Meteorol. Soc., 106, 85-100.

Zhang, J., Lee, X., Song, G., and Han, S., 2011: Pressure correction to the long-term measurement of carbon dioxide flux. Agric. For. Meteorol., 151, 70-77. 